\title{
A Review of Anti-Angiogenic Targets for Monoclonal Antibody Cancer Therapy
}

\author{
Deok-Hoon Kong, Mi Ra Kim, Ji Hye Jang, Hee-Jun Na * and Sukmook Lee * \\ Research Center, Scripps Korea Antibody Institute, Chuncheon 200-701, Korea; kong0131@skai.or.kr (D.-H.K.); \\ cslove526@skai.or.kr (M.R.K.); jjh717@skai.or.kr (J.H.J.) \\ * Correspondence: hee7606@skai.or.kr (H.-J.N.); Lees@skai.or.kr (S.L.); \\ Tel.: +82-33-250-8094 (H.-J.N.); +82-33-250-8096 (S.L.); Fax: +82-33-250-8088 (H.-J.N. \& S.L.)
}

Received: 21 July 2017; Accepted: 14 August 2017; Published: 17 August 2017

\begin{abstract}
Tumor angiogenesis is a key event that governs tumor progression and metastasis. It is controlled by the complicated and coordinated actions of pro-angiogenic factors and their receptors that become upregulated during tumorigenesis. Over the past several decades, vascular endothelial growth factor (VEGF) signaling has been identified as a central axis in tumor angiogenesis. The remarkable advent of recombinant antibody technology has led to the development of bevacizumab, a humanized antibody that targets VEGF and is a leading clinical therapy to suppress tumor angiogenesis. However, despite the clinical efficacy of bevacizumab, its significant side effects and drug resistance have raised concerns necessitating the identification of novel drug targets and development of novel therapeutics to combat tumor angiogenesis. This review will highlight the role and relevance of VEGF and other potential therapeutic targets and their receptors in angiogenesis. Simultaneously, we will also cover the current status of monoclonal antibodies being developed to target these candidates for cancer therapy.
\end{abstract}

Keywords: antibody; cancer therapy; therapeutic target; tumor; tumor angiogenesis; VEGF

\section{Introduction}

Angiogenesis is a physiological process in which new blood vessels are formed from pre-existing vessels. It occurs during normal growth and development, as well as during wound healing [1-3]. Under physiological conditions, angiogenesis is tightly regulated by the complex and coordinated actions of pro-angiogenic and anti-angiogenic factors according to the spatiotemporal requirements of cells or tissues [4]. To date, many pro-angiogenic factors and their cognate receptors have been identified, including vascular endothelial growth factor (VEGF), platelet-derived growth factor (PDGF), angiopoietin (Ang), hepatocyte growth factor (HGF), and epidermal growth factor (EGF) [5-10].

Tumor angiogenesis is a hallmark of cancer and plays a crucial role in providing oxygen and nutrients to tumor cells during cancer progression and metastasis [11,12]. Under pathological conditions, many pro-angiogenic factors and their receptors are upregulated; among these factors, VEGF is generally regarded as a key regulator of tumor angiogenesis [13-15]. Bevacizumab, an anti-VEGF antibody, was recently developed as a cancer therapy to suppress tumor angiogenesis $[16,17]$. Although bevacizumab is clinically effective for treating patients with a variety of cancers, it has frequent complications due to its inhibition of VEGF signaling in normal endothelial cells, which express high levels of VEGF receptors (VEGFRs). Importantly, bevacizumab treatment is associated with severe side effects, including bleeding, proteinuria, hypertension, gastrointestinal perforation, and stroke $[18,19]$. Furthermore, in glioblastoma multiforme patients, bevacizumab treatment is associated with the presence of tumor cells that have an infiltrative phenotype, and high levels of matrix metalloproteinase (MMP)-2 and membrane-type 1 MMP [20-22]. In addition, long-term 
bevacizumab treatment can lead to the development of drug resistance, due to the upregulation of other redundant tumor-derived angiogenic factors, including Ang, EGF, HGF, and PDGF [23-25].

Despite the wide-range of clinical usefulness of bevacizumab for cancer therapy, the identification of novel angiogenic therapeutic targets and development of novel drugs as alternative or combination treatments with existing drugs are needed to improve the survival and quality of life of cancer patients. In the present article, we review the role and relevance of VEGF/VEGFR and four other therapeutic targets in tumorigenesis, as well as the current status (Table 1) and mechanisms of action of therapeutic antibodies being developed for anti-angiogenic therapy (Figures 1 and 2).

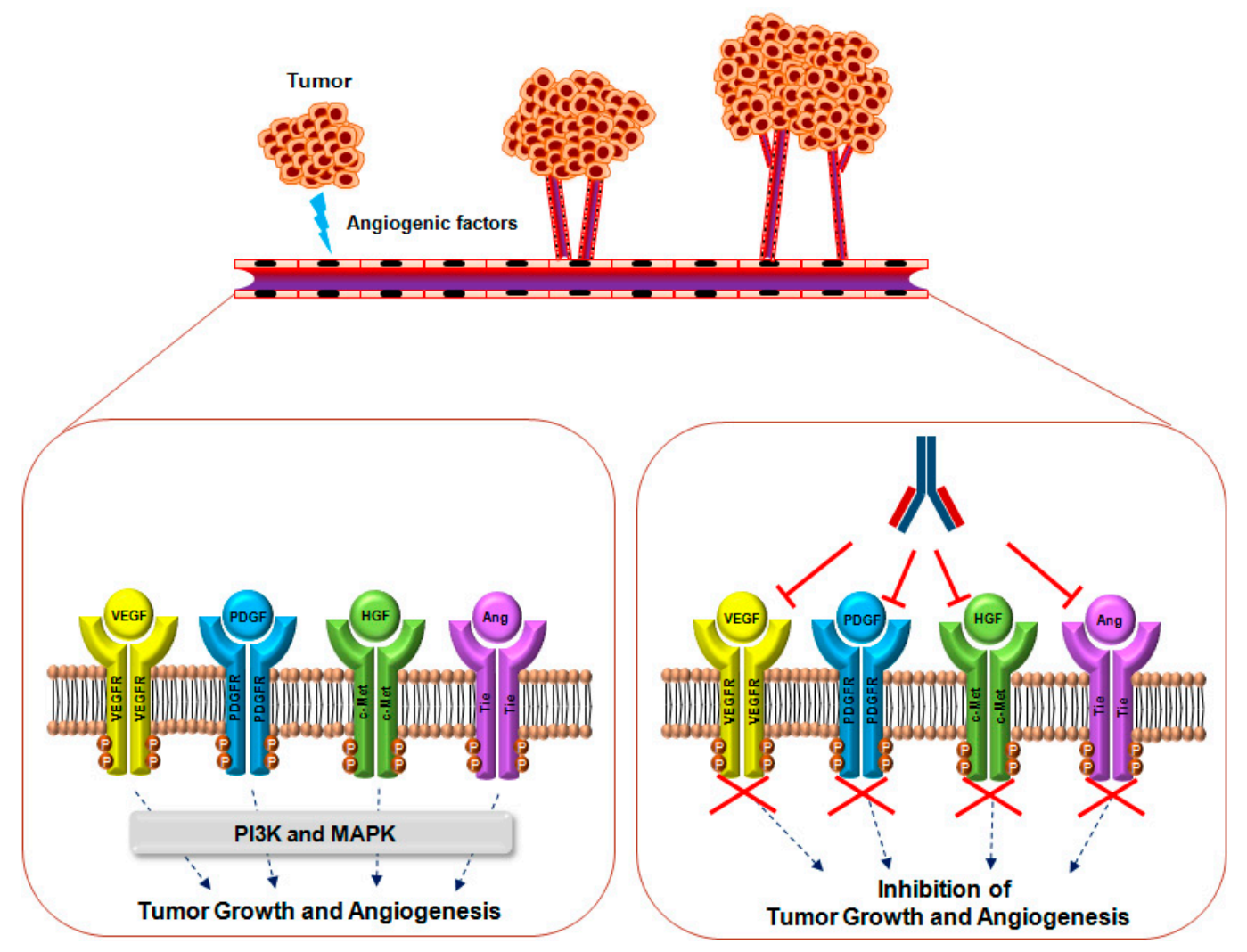

Figure 1. Mechanisms of action of monoclonal antibodies targeting VEGF, PDGF, HGF, Ang, and their receptors for suppressing tumor growth and angiogenesis. Under pathological conditions, including hypoxia, most tumor cells and/or adjacent cells upregulate the expression of many angiogenic factors, including VEGF, PDGF, HGF, and Ang, and secrete them within the tumor microenvironment. When these molecules bind their cognate receptors, receptor dimerization and autophosphorylation stimulate downstream signaling molecules including phosphatidylinositol-4,5-bisphosphate 3-kinase (PI3K)/v-Akt murine thymoma viral oncogene (Akt) and MAPK (dash lines) for the promotion of tumor growth and angiogenesis. Currently, most antibody therapeutics are being developed to block the interaction between agonists and their receptors ( $T$ arrows). 
Table 1. Selected examples of monoclonal antibodies currently in clinical use and development.

\begin{tabular}{|c|c|c|c|c|c|}
\hline Target & Antibody & Company/Institute & Antibody Type & Status & Indication \\
\hline VEGF-A & Bevacizumab (Avastin) & Genentech & Humanized, IgG1 & FDA approval & $\begin{array}{l}\text { Colorectal cancer, NSCLC, glioblastoma, breast } \\
\text { cancer, renal carcinoma, epithelial ovarian cancer }\end{array}$ \\
\hline VEGF-A, -B, PGF & Aflibercept (Zaltrap) & Regeneron & Fully human, IgG1 & FDA approval & Colorectal cancer \\
\hline VEGFR2 & Ramucirumab (Cyramza) & Imclone & Fully human, IgG1 & FDA approval, Phase II & $\begin{array}{l}\text { Advanced gastric or gastro-esophageal junction } \\
\text { adenocarcinoma, NSCLC, advanced or metastatic } \\
\text { urothelial carcinoma }\end{array}$ \\
\hline VEGFR2 & Tanibirumab & Pharmabcine & Fully human, IgG1 & Phase II & Recurrent glioblastoma \\
\hline PDGFR $\alpha$ & Olaratumab (Lartruvo) & Eli Lilly & Fully human, IgG1 & FDA approval & Soft tissue sarcoma \\
\hline Ang-2 & Nesvacumab (REGN910) & Regeneron & Fully human, IgG1 & Phase I & Advanced solid tumors \\
\hline Ang-1,-2 & AMG780 & Amgen & Fully human, IgG2 & Phase I & Advanced solid tumors \\
\hline Ang-2 & MEDI3617 & MedImmune LLC & Fully human, IgG1 & Phase I & Advanced solid tumors \\
\hline Ang-2 and VEGF & Vanucizumab & Genentech & Bispecific, IgG1 & Phase II & Colorectal cancer \\
\hline HGF & Rilotumumab (AMG102) & Amgen & Fully human, IgG2 & Phase I, II, III & $\begin{array}{l}\text { Gastric and esophagogastric junction cancer, } \\
\text { NSCLC, metastatic colorectal cancer, prostate } \\
\text { cancer, renal cell carcinoma }\end{array}$ \\
\hline HGF & Ficlatuzumab (SCH900105) & $\begin{array}{c}\text { AVEO } \\
\text { Pharmaceuticals }\end{array}$ & Humanized, IgG1 & Phase I, II & Head and neck squamous carcinoma, NSCLC \\
\hline HGF & TAK-701 & Galaxy Biotech & Humanized, IgG1 & Phase I & Advanced solid tumors \\
\hline $\begin{array}{l}\text { Tyrosine-protein kinase } \\
\text { Met (c-MET) }\end{array}$ & Onartuzumab (MetMab) & Genentech & Humanized, IgG1 & Phase I, II, III & $\begin{array}{l}\text { NSCLC, glioblastoma, gastric cancer, } \\
\text { hepatocellular carcinoma, breast cancer }\end{array}$ \\
\hline c-MET & Emibetuzumab (LY-2875358) & Eli Lilly & Humanized, IgG4 & Phase II & NSCLC, gastric cancer \\
\hline CLEC14a & - & Univ. of Birmingham & Mouse & Preclinical & Undetermined as yet \\
\hline CLEC14a & - & $\begin{array}{l}\text { Scripps Korea } \\
\text { Antibody Institute }\end{array}$ & Fully human, IgG1 & Preclinical & Undetermined as yet \\
\hline
\end{tabular}


A

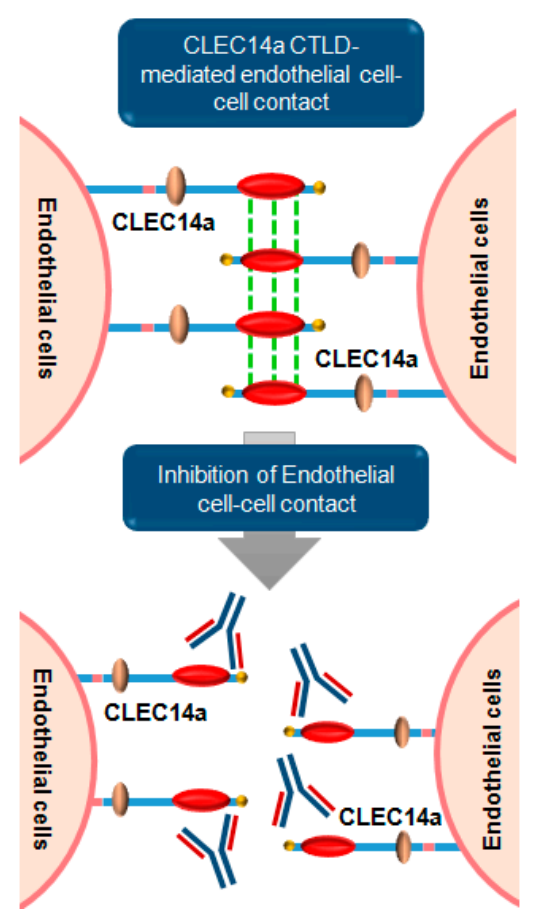

B

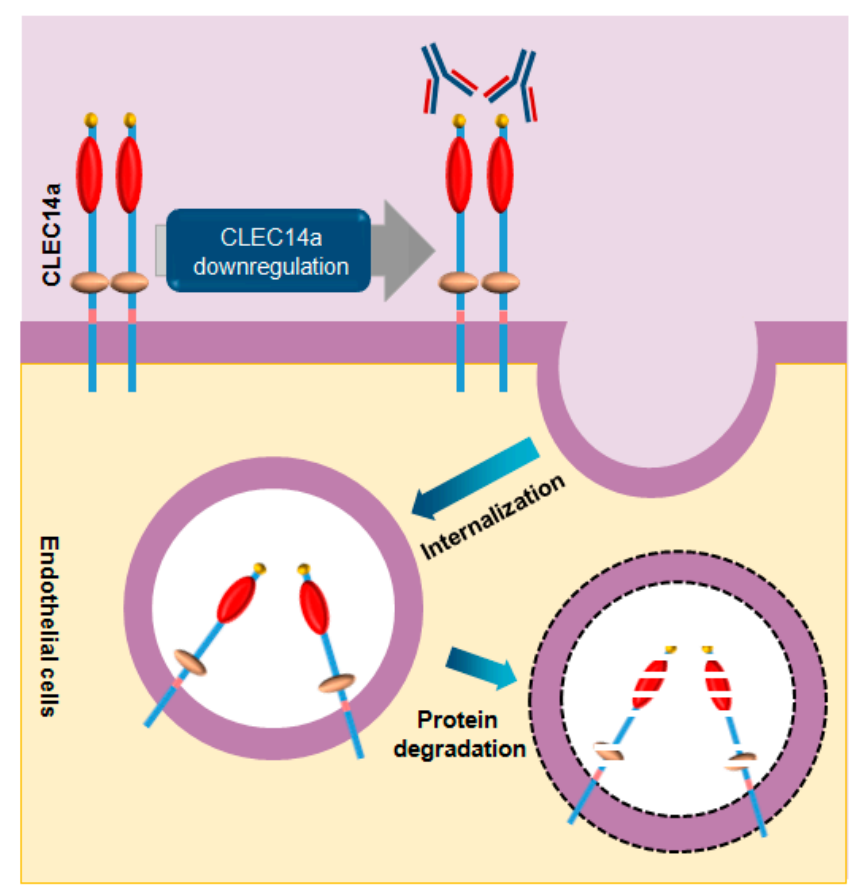

Figure 2. Dual mode of action of a monoclonal antibody targeting the CLEC14a (C-type domain family 14 member) CTLD (C-type lectin-like domain) in cancer. (A) In tumor angiogenesis, the CLEC14a CTLD (red) plays a key role in mediating endothelial cell-cell contacts. When a targeting antibody binds to the CTLD of CLEC14a on tumor vessels, endothelial cell-cell contacts are inhibited, resulting in inhibition of tumor angiogenesis; (B) Simultaneously, binding of the antibody to CLEC14a on endothelial cells induces internalization of CLEC14a and eventually leads to its downregulation. These molecular mechanisms are important for suppressing CLEC14a-mediated tumor angiogenesis.

\section{VEGF Signaling}

\subsection{Overview}

VEGF, first identified as a factor that promotes vascular permeability and vascular endothelial cell mitosis in the 1980s, is a key player in angiogenesis, as well as in endothelial proliferation, migration, and nitric oxide (NO) release [26-28]. The mammalian VEGF proteins are dimeric glycoproteins with a molecular weight of approximately $40 \mathrm{kDa}$. Although VEGF-A is the most well characterized VEGF isoform, the VEGF family consists of five distinct isoforms: VEGF-A, VEGF-B, VEGF-C, VEGF-D, and placenta growth factor (PIGF). Structurally, VEGF proteins have eight regularly spaced cysteine residues, which form intramolecular disulfide bonds that generate three loops; two intermolecular disulfide bonds allow for a homodimer structure between two VEGF molecules [29,30]. In addition, VEGF has various alternative splice variants, which exhibit different binding affinity for VEGFR co-receptors, including neuropilins and heparin sulfate proteoglycans [31]. For instance, VEGF-A, VEGF-B, and PlGF can be divided into five (VEGF-A121, VEGF-A145, VEGF-A165, VEGF-A189, and VEGF-A206), two (VEGF-B167 and VEGF-B186), and four (PlGF-1, PlGF-2, PlGF-3, and PlGF-4) variants [32-34]. Among the VEGF-A variants, VEGF-A165 and VEGF-A189 bind neuropilins and heparin sulfate proteoglycans, whereas VEGF-A121 does not bind either [31]. Importantly, this molecular diversity alters bioavailability and activity, which in turn, allows for the initiation of various cellular responses.

VEGF-mediated cellular functions occur via the activation of three receptors: VEGFR-1 (Flt-1), VEGFR-2 (KDR/Flk-1), and VEGFR-3 (Flt-4). VEGFRs are members of the receptor tyrosine kinase (RTK) superfamily and are composed of an extracellular domain with seven immunoglobulin (Ig)-like 
domains, a transmembrane domain, a juxtamembrane domain, and an intracellular domain with a split tyrosine kinase domain and C-terminal tail [35]. Ig-like domains are involved in ligand binding; in particular, Ig-like domains 2 in VEGFR-1 and Ig-like domains 3 in VEGFR-2 are associated with ligand-binding site and ligand-binding specificity, respectively [32]. Upon ligand binding, VEGFRs form homo- and heterodimers, which induce tyrosine transphosphorylation of the intracellular kinase domains and activates signal transduction.

VEGF signaling is one of the major signaling pathways required for embryonic vascular development and angiogenesis. VEGF-A, VEGF-B, and P1GF are constitutive VEGFR-1 agonists that induce migration and proliferation. In endothelial cell and macrophages, VEGFR-1 initiates migration by stimulating the phosphatidylinositol-4,5-bisphophate 3-kinase (PI3K)/Akt-Rac1 pathway through a receptor for activated protein kinase C 1 [36]. PI3K pathway activation by VEGFR-1 is also linked to endothelial cell proliferation and tubulogenesis [37]. In addition, stimulation of monocyte VEGFR-1 induces migration through the activation of several intracellular signaling molecules, including PI3K, Akt, extracellular signal-regulated kinases (ERK)1/2, and p38 mitogen-activated protein kinase (MAPK) [38]. In particular, VEGF-A activation of VEGFR-2 initiates PLC $\gamma$ interaction with the Tyr1175 residue of internalized VEGFR-2 in early endosome antigen 1-positive endosomes [32,39]. This leads to subsequent cascades that activate $\mathrm{Ca}^{2+}$-dependent rapidly accelerated fibrosarcoma (RAF)-mitogen-activated protein kinase kinase (MEK)-ERK1/2 and calmodulin-calcineurin-nuclear factor of activated $\mathrm{T}$ cells pathways, which together promote endothelial cell migration, proliferation, and homeostasis [32,39]. The Tyr951 residue of VEGFR-2 also provides a binding site for the v-sarcoma viral oncogene homolog (SRC) homology 2 (SH2) domain of T-cell-specific adaptor protein [32,39,40]. Interaction of T-cell-specific adaptor protein with VEGFR-2 leads to the activation of Akt signaling, which determines endothelial cell shape, adhesion, survival, and vessel permeability [32,39,40]. In addition, Akt activation by VEGFR-2 stimulates endothelial nitric oxide synthase, inducing release of NO into the extracellular space, which promotes vasodilation in adjacent smooth muscle cells [39]. VEGF-C or VEGF-D activation of VEGFR-3 plays a critical role in lymphangiogenesis; in lymphatic endothelial cells, SHC and growth factor receptor bound protein 2 (GRB2) adaptor proteins are recruited to activated VEGFR-3 and promote ERK1/2 and PI3K/Akt pathway, which is critical for lymphatic endothelial cell migration [41,42].

\subsection{Relevance of VEGF and VEGFR in Cancer}

VEGF/VEGFR signaling is critical for vessel development during embryogenesis and tumorigenesis $[43,44]$. In particular, VEGF-A and its receptors have been well studied in physiological and pathological neovascularization processes, such as tumor angiogenesis. Several studies have demonstrated that VEGF-A is induced by exposure to hypoxic conditions and secreted by tumor cells and tumor-associated stroma [45-47]. VEGFRs are also present in both liquid and solid tumors, such as leukemia, non-small cell lung cancer (NSCLC), gastric cancer, and breast cancer [48-51]. In NSCLC, the five-year survival rates of patients expressing low and high VEGF mRNA were $77.9 \%$ and $16.7 \%$, respectively [52]. Xenograft mouse models of VEGF-A-deficient lung carcinoma display delayed tumor growth and reduced tumor weight, as well as the inhibition of angiogenesis and induction of apoptosis [49]. In breast cancer, VEGF-A has been reported to promote the proliferation, survival, and metastasis of breast cancer cells in vitro and in vivo. VEGF-A expression in breast cancer cells, including MCF-7, BT-474, and T47-D cells, induces proliferation and survival in vitro through Bcl-2, an anti-apoptotic protein [50]. Additionally, inhibition of VEGF-A in a xenograft mouse model of murine breast carcinoma $4 \mathrm{~T} 1$ cells suppresses primary tumor growth and prevents pulmonary metastases [53].

In addition to NSCLC and breast cancer, overexpression of VEGF-A and VEGF-C occurs in gastric cancer. In gastric cancer patients, VEGF-A and VEGF-C are associated with large tumor size, higher peritumoral lymphatic vessel density, microvessel density, lymphatic vessel invasion, lymph node metastasis, and worse prognosis [51]. Furthermore, silencing of VEGF-A and VEGF-C significantly 
inhibits cell proliferation, tumor growth, and tumor size in vitro and in vivo [51]. The tumor-promoting effects of VEGF/VEGFR have been demonstrated in other cancer types, including neuroblastoma, prostate cancer, and hepatocellular carcinoma [54-56]. Together, these studies suggest that the VEGF signaling axis is involved in multiple aspects of cancer development and may be a good prognostic and therapeutic target for cancer patients.

\subsection{Monoclonal Antibodies Targeting VEGF and VEGFR}

Monoclonal antibody-based therapy is one of the most important strategies for treating patients with various diseases, including solid tumors, hematological malignancies, immunological disorders, and eye diseases [57-59]. So far, there are more than 40 therapeutic antibodies approved by the United States Food and Drug Administration (US FDA) for various indications, and many more are currently being evaluated in clinical trials [60].

Bevacizumab (Avastin ${ }^{\circledR}$, Genentech, San Francisco, CA, USA) is a recombinant humanized immunoglobulin $\mathrm{G}$ (IgG) monoclonal antibody that targets VEGF-A and inhibits formation of the VEGF-A and VEGFR-2 complex [61]. In 2004, bevacizumab was first approved by the US FDA to treat metastatic colorectal cancer in combination with standard chemotherapy [62]. Currently, it is widely used to treat various cancers, including metastatic non-squamous NSCLC, metastatic renal cell carcinoma, breast cancer, epithelial ovarian cancer, and glioblastoma [63-67]. Due to the clinical validation of bevacizumab as a specific inhibitor of interaction between VEGF-A and VEGFR2, the increasing numbers of monoclonal antibodies in development has targeted VEGR2 as a promising molecular target for anti-angiogenesis.

Aflibercept (Zaltrap ${ }^{\circledR}$, Regeneron pharmaceuticals, Tarrytown, NY, USA) is an Fc fusion protein consisting of the extracellular domains of VEGFR-1 and VEGFR-2 fused with the Fc domain of human IgG [68]. It acts as a VEGF trap that inhibits the activity of VEGF isoforms, including VEGF-A, VEGF-B, and PIGF, and suppresses tumor angiogenesis. In 2012, the US FDA approved aflibercept to treat patients with metastatic colorectal cancer that is resistant to or has progressed following an oxaliplatin-based regimen [69]. Aflibercept (Eylea) was also approved by the US FDA in 2011 for the treatment of wet age-related macular degeneration, the leading cause of blindness in the elderly $[70,71]$. Furthermore, although bevacizumab is not approved by the FDA for this indication, it has been prescribed off-label because of its cost effectiveness and significant inhibitory effect on VEGF-dependent neovascularization [72,73].

Ramucirumab (Cyramza ${ }^{\circledR}$, ImClone Systems Incorporated, Bridgewater, NJ, USA) is a fully human monoclonal antibody that specifically targets VEGFR2 by blocking its interaction with VEGF ligands [74-76]. In 2014, the US FDA approved ramucirumab for the treatment of advanced gastric or gastro-esophageal junction adenocarcinoma and metastatic non-small-cell lung carcinoma [77,78]. Unfortunately, ramucirumab has not been significantly effective in clinical trials for breast and liver cancer, although it is currently in a phase III trial for locally advanced or metastatic urothelial carcinoma [79-81].

Tanibirumab is a fully human monoclonal antibody developed by PharmAbcine (Daejon, Korea). It specifically binds VEGFR-2 and blocks binding of VEGFR ligands, including VEGF-A, VEGF-C, and VEGF-D [82]. In 2013, a phase I trial of tanibirumab in patients with solid tumors refractory to standard chemotherapy was finished with good safety and efficacy results [83].

\section{PDGF Signaling}

\subsection{Overview}

In the 1970s, PDGF was first isolated from platelet extracts and identified as a mitogenic factor in in vitro cultures of mammalian cells, including fibroblasts, smooth muscle cells, and glial cells [84,85]. Heldin et al. reported that purified PDGF stimulates tyrosine kinase activity in membranes prepared from human fibroblasts, suggesting that PDGFR had tyrosine kinase activity [86]. 
PDGFs are assembled in the endoplasmic reticulum as inactive precursor disulfide-linked homodimers composed of AA-, BB-, CC-, and DD-polypeptide chains, and the heterodimer PDGF-AB [87]. Generally, the structure of PDGF family members consists of a growth factor domain of about 100 amino acid residues that is involved in receptor-binding and dimerization and a prodomains of various length that is an attached amino acid sequence found in N-terminal extension [88-90]. These isoforms are activated by proteolytic processing: PDGF-AA, -AB, and -BB have short $\mathrm{N}$-terminal extensions that are cleaved by intracellular proteolysis in secretory vesicles, whereas PDGF-CC and -DD have a distinct protein domain called the CUB-domain, which is cleaved by extracellular proteolysis [87]. Active isoforms of PDGF bind to the $\alpha$ - and $\beta$-RTKs, PDGFR $\alpha$ and PDGFR $\beta$, and induce the activation of downstream signaling pathways following tyrosine autophosphorylation [84].

PDGFRs are transmembrane proteins with intrinsic tyrosine kinase activity. The two PDGFRs are composed of an extracellular domain with five Ig-like domains, a transmembrane domain, and an intracellular portion that contains the kinase domain [89]. PDGFRs are activated by ligand binding to Ig-like domains 2 and 3, which are further stabilized by dimerization, resulting in direct receptor-receptor interactions involving Ig-like domain 4 [91,92]. Upon ligand binding, PDGFR dimerization induces the transphosphorylation of the cytoplasmic catalytic domain, where tyrosine residues serve as docking sites for downstream molecules, which include members of the MAPK and PI3K signaling pathways [93].

PDGFR activation of the rat sarcoma (RAS)-MAPK pathway is initiated when the SH2 domain of GRB2 binds to a PDGFR phosphotyrosine residue, forming a complex with Son of sevenless homology 1 (SOS1) through its SH3 domains [93]. Son1 in turn induces the downstream activation of RAF-1 and MAPK cascades by activating RAS, leading to cell growth, differentiation, and migration [93]. PDGF stimulates the PI3K pathway through the activation of serine/threonine kinases, such as Akt/PKB, PKC, P70 S6 kinase, JNK, and small GTPases of the Rho family, leading to actin reorganization, directed cell movements, stimulation of cell growth, and inhibition of apoptosis [93-98].

\subsection{The Role and Relevance of PDGF and PDGFR in Cancer}

Signal transduction via PDGF and PDGFR has been implicated in several physiological and pathological processes, including wound healing, embryogenesis, bone formation, and tumor growth [93,99-102]. PDGF and PDGFR signaling is also associated with the normal development of the kidney, brain, and respiratory systems [103]. Under physiological conditions, endothelial-derived PDGF-BB activates pericytes and smooth muscle cells through paracrine signals, which in turn, affects vascular remodeling, maturation, and stability. PDGF-BB also modulates endothelial proliferation, migration, and tube formation, and contributes to angiogenesis in vitro; in contrast, PDGF-AA has no such effect or induces a weak angiogenic response [84]. PDGF-CC promotes the angiogenesis of the mouse cornea through PDGFR $\alpha \alpha$ and $-\alpha \beta$ dimers [104]. In addition, PDGF-CC is abundantly expressed in angiogenic tissues, such as the placenta, ovary, and embryo $[105,106]$. Finally, PDGF-DD plays an important role in increasing interstitial fluid pressure, macrophage recruitment, and blood vessel maturation during angiogenesis in the skin and skeletal muscles [107]. Interestingly, inhibition of PDGF-DD also suppresses ocular neovascularization [108].

As mentioned above, PDGF and PDGFR play important roles in vascular remodeling, maturation, and stability during angiogenesis. Since angiogenesis is crucial for tumor growth and metastasis, the relationship between PDGF and PDGFR and carcinogenesis has been studied for several decades. Overexpression of PDGFR is mainly observed in colorectal cancers and is closely associated with angiogenesis, invasion, and metastasis [109]. Its overexpression also correlates with poor patient prognosis [109]. In addition to colorectal cancers, overexpression of PDGF and PDGFR occurs in brain tumors like glioblastoma. In particular, PDGF-CC affects the maturation and stabilization of blood vessels in a xenograft mouse model of VEGF-CC-overexpressed human glioblastoma and these functions are weakened in response to anti-VEGF therapy [110]. Furthermore, PDGF-DD and 
PDGFR $\beta$ are upregulated in most primary and metastatic prostate cancer cells. Overexpression of PDGF-DD in a xenograft mouse model of prostate cancer and in PC3 prostate cancer cells promotes invasiveness and epithelial-mesenchymal transition, respectively [87]. Moreover, siRNA-mediated knockdown of PDGFR $\alpha$ and PDGFR $\beta$ suppresses prostate cancer cell growth by the suppression of angiogenesis in a prostate cancer xenograft model $[87,111]$. The PDGF/PDGFR pathway also plays a role in transforming growth factor- $\beta$-mediated hepatocellular carcinoma and epithelial-mesenchymal transition-mediated breast cancer progression $[112,113]$.

Small molecule compounds targeting PDGFRs have been intensively investigated and include imatinib, sunitinib, regorafenib, and pazopanib [87]. These inhibitors suppress the activation of PDGFRs, as well as other kinases, such as Abl kinase, Kit, VEGFR, Raf, and FGFR [87]. Currently, they are approved in the clinic for first- or second-line treatment of various cancers, including metastatic colorectal cancer, metastatic renal cell carcinoma, and gastrointestinal stromal tumors [114]. However, the broad range of toxicity and side effects due to off-target effects of these compounds are major obstacles yet to be overcome.

\subsection{Monoclonal Antibodies Targeting PDGF and PDGFR}

PDGF and PDGFR are overexpressed in many human tumor types and contribute to cancer progression by promoting blood vessel maturation and angiogenesis, resulting in poor response to chemotherapy and decreased patient survival. Olaratumab (LARTRUVO ${ }^{\circledR}$, Eli Lilly, Indianapolis, IN, USA) is a fully human monoclonal antibody that targets human PDGFR $\alpha$ with high affinity $(\mathrm{Kd}=40 \mathrm{pM})[115,116]$. It blocks ligand binding to PDGFR $\alpha$, inhibits tyrosine phosphorylation of the receptor, and suppresses ligand-induced phosphorylation of downstream signaling molecules [116]. In 2005, Loizos et al. first developed olaratumab using transgenic mice to produce fully human antibodies [115]. In preclinical studies, olaratumab reduced tumor growth of human glioblastoma and leiomyosarcoma [115]. In a prostate cancer xenograft model, targeting PDGFR $\alpha$ with olaratumab delayed the progression of early skeletal metastatic foci and reduced the size of skeletal tumors [117]. Olaratumab had also no apparent adverse effects when administered to cynomolgus monkeys at doses up to $75 \mathrm{mg} / \mathrm{kg}$ per week [118]. Based on its safety and anti-tumor activity in preclinical studies, olaratumab entered clinical development. In a phase I study in patients with advanced solid tumors, olaratumab had no dose-limiting toxicities and significant anti-tumor activity [118]. Given these results and the improvement of median survival and progression-free survival, the US FDA granted accelerated approval to olaratumab in 2016 for the treatment of patients with soft tissue sarcoma that is not amenable to curative treatment with radiotherapy or surgery [119].

\section{Ang Signaling}

\subsection{Overview}

Ang and its receptor, tyrosine kinase with Ig-like and EGF-like domains (Tie) receptor, comprise a major signaling node that modulates vascular development and remodeling [120]. Angs are $\sim 70 \mathrm{kDa}$ glycoproteins consisting of four distinct isoforms: Ang-1, Ang-2, Ang-3, and Ang-4. Ang-1 and Ang-2 were first isolated using a secretion-trap expression cloning and low stringency DNA homology cloning approach [121,122]. Subsequently, Ang-3 and Ang-4 were identified as the mouse and human orthologues, respectively [121]. Among these members, Ang-1 and Ang-2 share approximately 60\% amino acid sequence identity, and are expressed in the vascular endothelium [123]. Ang-3, the mouse orthologue of Ang-4, is expressed in a number of murine tissues, and Ang-4 is highly expressed in human lung [121,124].

In the early 1990s, Tie receptors were first identified as endothelial cell RTKs. There are two Tie receptors, Tie- 1 and Tie-2. Ang directly binds Tie-2, while Tie-1 lacks a ligand [121,122,125,126]. Tie-1 and Tie-2 are composed of an extracellular domain, a transmembrane domain, and an intracellular domain that transduces downstream signaling [127]. At the $\mathrm{N}$-terminus, the extracellular domain has 
two Ig-like domains for Ang binding, followed by EGF-like domains, another Ig-like domain, and three fibronectin type III-like domains [127]. The intracellular domain possesses a split tyrosine kinase domain and carboxy-terminal tail.

The binding of Ang to Tie-2 leads to receptor dimerization and autophosphorylation at five tyrosine residues in the intracellular kinase domain, resulting in vessel remodeling and vessel maturation during embryonic development and adult vessel homeostasis [8,128]. Ang-1 is a constitutive agonist of Tie-2 for endothelial cell survival, whereas Ang-2 is generally considered to be an antagonist that competes with Ang- 1 for Tie-2 binding; both Ang-1 and Ang- 2 have comparable binding affinities for Tie-2 [123,129,130]. Upon binding of Ang-1, Tie-2 induces a number of intracellular signaling pathways, including PI3K and MAPK. The p85 subunit of PI3K interacts with Tyr1101 of activated Tie-2 and stimulates the PI3K-Akt pathway, which promotes endothelial cell survival and NO release [130,131]. This occurs through the inhibition of Smac, a protein that stimulates cytochrome c-dependent caspase activation and release from mitochondria [132]. This, in turn, increases the expression of survivin and activation of endothelial nitric oxide synthase [132]. This pathway also inhibits forkhead transcription factor FKHR and prevents endothelial cell death [133].

The RAS-RAF-MAPK pathway is also initiated in endothelial cells by the interaction of activated Tie-2 with the SH2 domain of GRB2, which initiates the synthesis of platelet activating factor, anti-inflammatory responses, migration, proliferation, permeability, and morphogenesis [130,132]. Cell migration is stimulated when the downstream of kinase-related docking protein is recruited to Tie-2 and interacts with the non-catalytic region of the tyrosine kinase Nck and serine/threonine p21-activated kinase $[130,132,134]$. Tie-2 also mediates anti-inflammatory and anti-apoptotic activity by interacting with the A20-binding inhibitor of nuclear factor-kB-2 [135,136].

\subsection{The Role and Relevance of Ang and the Tie Receptor in Cancer}

Ang/Tie signaling is a fundamental process for proper embryonic development. The overexpression of Ang-2 and a potent Ang-1 variant (COMP-Ang-1) in a hindlimb ischemic model and hypercholesterolemic mouse model induces postnatal and cavernous angiogenesis, demonstrating that Ang/Tie signaling is an essential regulator of vascular development under physiological conditions $[137,138]$.

Under pathological conditions, such as cancer, Ang/Tie signaling plays important and rate-limiting roles in the early stages of tumor vascularization. The roles of Ang-3 and Ang-4 in pathological conditions are relatively unknown, whereas many studies have demonstrated the importance of Ang-1 and Ang-2 in tumor growth and tumor-associated angiogenesis. Ang- 2 is widely expressed in various cancers including stomach, colon, hepatocellular carcinoma, melanoma, and NSCLC, and plays a distinct role in tumor pathogenesis [139-143]. In an Ang-2-transfected colon cancer xenograft model, Ang-2 led to increased angiogenesis and tumor growth [141]. Moreover, the forced expression of Ang-2 promotes metastasis, while Ang-2 inhibition represses tumor angiogenesis and metastasis in mouse models of spontaneous carcinogenesis [144,145]. In addition, Ang-2-deficiency in mice implanted with lung carcinoma and melanoma retards tumor growth and increases tumor vascular maturation and pericyte coverage compared to wild-type mice [146]. In contrast to the tumor-promoting effects of Ang-2, the role of Ang-1 in cancer is controversial. Forced expression of Ang-1 increases tumor growth in a model of rat glioma, as well as in animal models of plasma cell tumor $[147,148]$. In contrast, Ang-1 overexpression reduces tumor growth in multiple other cancers, including squamous cell carcinoma, breast cancer, and colon cancer [149-151]. These results suggest that modulation of the Ang-2 to Ang-1 ratio may be important for the treatment of tumor growth and angiogenesis.

\subsection{Monoclonal Antibodies Targeting Ang and Tie Receptors}

Ang/Tie signaling is a key regulator of tumor vascular remodeling. Generally, it is thought that Ang- 1 mediates vessel stabilization and maturation, whereas Ang-2 induces vessel destabilization 
and permeability. Ang-2 is upregulated in a number of human cancers, and high levels of circulating Ang-2 are associated with a poor prognosis in breast cancer, gastric cancer, hepatocellular carcinoma, and lung cancer [152].

Nesvacumab is a fully human monoclonal antibody developed by Regeneron Pharmaceuticals (Tarrytown, NY, USA). It selectively binds Ang-2 with high affinity (Kd $=24 \mathrm{pM})$ and blocks Ang-2 binding to Tie-2 [153]. In preclinical studies, nesvacumab significantly inhibited tumor growth in xenograft models of prostate adenocarcinoma, colorectal adenocarcinoma, and epidermoid carcinoma $[153,154]$. Nesvacumab also had no apparent adverse toxic effects in Sprague Dawley rats and cynomolgus monkeys [153]. On the basis of its safety and anti-tumor activity in preclinical studies, nesvacumab entered phase I trials for advanced solid tumors, which reported that nesvacumab had anti-tumor activity within an acceptable safety profile [153]. In addition, the combination trials of nesvacumab with aflibercept have completed enrollment (Clinical trials information: NCT01688960).

AMG780 is a fully human monoclonal antibody developed by Amgen (Thousand Oaks, CA, USA) that binds to Ang-1 and Ang-2 [155]. It was isolated from a human antigen-binding fragments (Fab) library using bio-panning with phage display technology. Currently, phase I trials in patients with advanced solid tumors have been completed; the results demonstrate that AMG 780 can be administered at doses up to $30 \mathrm{mg} / \mathrm{kg}$ every two weeks, with anti-tumor effects in six of 31 evaluable patients [156].

Vanucizumab is a humanized bispecific antibody developed by Genentech (San Francisco, CA, USA) that specifically binds to Ang-2 and VEGF-A [157]. Vanucizumab effectively reduced tumor growth and had anti-angiogenic activity in a xenograft model of colon cancer, and a phase II trial for patients with metastatic colorectal cancers was completed in 2017 (Clinical trials information: NCT02141295) [158].

MEDI3617 is a fully human monoclonal antibody developed by Medlmmune LLC (Gaithersburg, MD, USA) that neutralizes Ang-2 by blocking its binding to Tie-2 [159]. In several xenograft models of colorectal carcinoma, renal carcinoma, hepatocellular carcinoma, lung carcinoma, colorectal carcinoma, and ovarian carcinoma, MEDI3617 significantly inhibited tumor growth by the modulation of tumor angiogenesis [159]. Currently, MEDI3617 had an acceptable safety profile in phase I trials for advanced solid tumors (Clinical trials information: NCT01248949).

\section{HGF Signaling}

\subsection{Overview}

In 1984, Nakamura et al. identified a putative hepatotrophic factor, named HGF, in the serum of hepatectomized rats [160]. HGF is secreted by mesenchymal cells as an inert precursor single-chain, and is converted into its bioactive form via cleavage by extracellular proteases, such as urokinase-type plasminogen activator, HGF activator, factors XII and XI, matriptase, and hepsin [161]. It plays a key role in cell proliferation, survival, motility, scattering, differentiation, and morphogenesis [161]. The mature form of HGF, also known as scatter factor, is composed of two subunits (a $69 \mathrm{kDa}$ $\alpha$-subunit and a $34 \mathrm{kDa} \beta$-subunit), which are linked by a disulfide bond [162]. The $\alpha$-subunit contains an $\mathrm{N}$-terminal hairpin loop followed by four kringle domains, with an 80 amino acid double-looped structure formed by three internal disulfide bridges for each kringle domain [163]. The $\beta$-subunit consists of the serine proteinase homology domain, but lacks proteolytic activity [163]. The active form of HGF binds to the c-MET proto-oncogene and induces the phosphorylation of tyrosine residues on c-MET, which initiates signal transduction upon recruitment of downstream adaptor molecules.

c-MET is also a member of the RTK family, and was identified as the HGF receptor in 1992 [164]. It is expressed in epithelial cells of many organs, including the liver, pancreas, prostate, kidney, muscle, and bone marrow [165]. Structurally, c-MET is a heterodimer composed of a $50 \mathrm{kDa} \alpha$-chain and a $145 \mathrm{kDa} \beta$-chain [164]. The extracellular domain of the $\beta$-chain has three domains: a semaphorin (Sema) domain, a plexin-semaphorin-integrin domain, and four immunoglobulin-plexin-transcription domains [163]. The $\mathrm{N}$-terminal Sema domain is linked to the $\alpha$-chain by a disulfide bond that 
includes the entire $\alpha$-subunit and part of the $\beta$-subunit [163]. The plexin-semaphorin-integrin domain follows the Sema domain and includes four disulfide bonds [163]. The intracellular domain consists of a juxtamembrane domain, a tyrosine kinase catalytic domain, and a C-terminus tail [166]. Phosphorylation of Tyr1234 and Tyr1235 within the kinase domain promotes enzyme activity, whereas phosphorylation of Ser985 and Tyr1003 in the juxtamembrane domain downregulates kinase activity [167]. Other phosphorylation sites in the C-terminal tail, Tyr1349 and Tyr1356, act as multifunctional docking sites for recruitment of signal transducers and adaptors [165].

Like other RTKs, binding of HGF to c-MET leads to receptor homodimerization and autophosphorylation of tyrosine residues within the intracellular domain. This initiates signal transduction through recruitment of adaptor proteins, including GRB2 and SHC, and effector molecules like PI3K and SRC [168-170]. MAPK signaling (described above) is one of the main signaling pathways downstream of HGF/c-MET and leads to cell proliferation, motility, and cell cycle progression [163,171]. The PI3K pathway, another HGF/c-MET effector pathway, also mediates cell survival through Akt [172]. In addition, c-MET directly stimulates the SRC-FAK cascades to induce cell migration and promote anchorage-independent growth $[170,173,174]$. c-MET signaling is also mediated by co-receptors, such as CD44v6, integrin $\alpha 6 \beta 4$, and GPCRs that physically associate with c-MET at the cell surface [175-177].

\subsection{The Role and Relevance of HGF and c-MET Signaling in Cancer}

HGF is a motility and morphogenic factor. HGF interacts with c-MET via an autocrine and/or paracrine signaling loop and participates in a variety of biological responses, such as embryonic development, epithelial branching morphogenesis, postnatal organ regeneration, wound healing, and tumor development [178]. Zhu et al. first demonstrated that c-MET signaling is essential for HGF-induced motogenic, invasive, and morphogenic responses in Madin-Darby canine kidney epithelial cells [179]. c-MET knockout mice have impeded skeletal muscle formation in the limb and diaphragm; in addition, mice lacking HGF die in utero due to reduced liver size and loss of parenchymal cells $[180,181]$. Together, these in vivo studies suggest that HGF/c-MET signaling is essential for proper development and multiple biological functions, including cell growth, shape, and movement.

c-MET was first isolated from human osteosarcoma cell lines and originally identified as an oncogene [182]. c-MET signaling is transiently activated in physiological process, but often constitutively activated in tumor cells. Expression of a form of c-MET, containing a translocating promoter region, causes mammary tumor development, as well as the development of other malignancies in transgenic mice [183]. This c-MET translocation has also been found in human gastric cancer precursor lesions [184]. In addition, cell lines that ectopically overexpress c-MET or HGF become transformed and metastasized in nude mice, and similarly, HGF or c-MET transgenic mice develop metastatic tumors [185-187]. Abnormal expression of HGF and c-MET has also been found in many kinds of solid cancers, including breast, colon, lung, ovary, kidney, prostate, bladder, and liver, and correlates with metastasis and poor prognosis [178].

\subsection{Monoclonal Antibodies Targeting HGF and c-MET}

HGF/c-MET signaling has been extensively studied as a therapeutic target for various solid tumors over the last few years. Rilotumumab (AMG102) is a fully human monoclonal antibody developed by Amgen (Thousand Oaks, CA, USA) that binds to HGF and blocks binding to c-MET, thereby inhibiting HGF/c-MET-driven signaling [188]. In preclinical studies, rilotumumab showed no toxicities in the cardiovascular, respiratory, or central nervous systems when administered at doses up to $100 \mathrm{mg} / \mathrm{kg}$ once weekly for up to one month [189]. It also exhibited multiple anti-tumor effects, including inhibition of tumor growth, induction of tumor regression, initiation of apoptosis, and abrogation of cell proliferation, in xenograft models of human glioblastoma cancer [190]. On the basis of its safety and anti-tumor activity in preclinical studies, rilotumumab entered clinical studies. In phase II clinical trials, patients with gastric and esophagogastric junction cancers treated with 
rilotumumab plus epirubicin, cisplatin, and capecitabine (ECX) had improved progression-free survival and overall survival compared to the placebo plus ECX group [191]. A phase III clinical trial of rilotumumab in combination with ECX was conducted in patients with gastric and esophagogastric junction cancers and terminated in 2016, due to no statistically significant improvement of overall survival (Clinical trials information: NCT01697072). In addition, many clinical trials of rilotumumab in combination with RTK inhibitors, such as placebo, avastin and erlotinib, have proceeded in patients with NSCLC, metastatic colorectal cancer, prostate cancer, and renal cell carcinoma (Clinical trials information: NCT01233687, NCT00788957, NCT00770848, and NCT00422019).

Ficlatuzumab (AV-299) is a humanized monoclonal antibody against HGF developed by AVEO Pharmaceuticals (Cambridge, MA, USA) [192]. It is a neutralizing antibody that inhibits the biological activity of HGF and c-MET [192]. In the H596 NSCLC xenograft model, the anti-tumor efficacy of ficlatuzumab was verified and increased with combination therapy with gefitinib and cetuximab, an EGFR inhibitor, compared with single agent treatment [178]. Based on this evidence, clinical trials were initiated to investigate the efficacy of ficlatuzumab for head and neck squamous cell carcinoma, advanced solid tumors, and NSCLC [192-194]. Preliminary anti-tumor activity and manageable adverse events were observed in phase I clinical trials for advanced solid tumors, and a dose of $20 \mathrm{mg} / \mathrm{kg}$ every two weeks was recommended for phase II trials [193]. Currently, a randomized phase II study with gefitinib alone or in combination with ficlatuzumab is underway for the treatment of NSCLC, but significant benefits of the combination therapy have not yet been shown [192].

TAK-701 (L2G7) is a humanized monoclonal antibody developed by Galaxy Biotech (Sunnyvale, CA, USA) and derived from murine L2G7 monoclonal antibodies with high affinity for HGF [195]. Preclinical studies over the last few years have reported its anti-tumor efficacy. In particular, the combination treatment of TAK-701 and gefitinib markedly reduces tumor growth in HCC827-HGF cell xenografts, a human NSCLC cell line with an activating EGFR mutation and HGF overexpression; this treatment also inhibited phosphorylation of c-MET, EGFR, ERK, and Akt [195]. A phase I clinical trial has been completed to test the safety, tolerability, and pharmacokinetics of TAK-701 in patients with advanced solid tumors, resulting no specific dose-limiting toxicities [196].

Onartuzumab (MetMAB) is a humanized monovalent monoclonal antibody against c-MET developed by Genentech (San Francisco, CA, USA) [197]. It was generated using Knob-into-hole technology, which allows antibody binding to its receptor in a one-to-one fashion [197]. Onartuxumab inhibits the binding of HGF and suppresses the ligand-induced phosphorylation of c-MET. Preclinical studies have demonstrated that onartuxumab significantly inhibits tumor growth in xenograft models of glioblastoma without having a detrimental impact on body weight [197]. In a phase II study, despite clinical efficacy of onartuxumab plus erlotinib in patients with MET-positive NSCLC, it had no efficacy in a randomized phase III study $[198,199]$. Nevertheless, other clinical trials for patients with glioblastoma, gastric cancer, hepatocellular carcinoma, and breast cancer have been completed (Clinical trials information: NCT01632228, NCT01662869, NCT01897038, and NCT01186991).

Emibetuzumab (LY-2875358) is a humanized bivalent monoclonal anti-c-MET antibody developed by Eli Lilly (Indianapolis, IN, USA) [200]. Emibetuzumab has internalization activities that depletes c-MET from the cell surface, preventing HGF binding to c-MET [201]. Emibetuzumab has significant anti-tumor efficacy in in vivo HGF-dependent glioma and HGF-independent gastric and NSCLC xenograft tumors [201]. In phase I trials for patients with NSCLC, treatment with emibetuzumab alone or in combination with erlotinib had no dose-limiting toxicities or serious adverse effects at a dose of $2000 \mathrm{mg}$ once every two weeks; a dose of $750 \mathrm{mg}$ once every two weeks was recommended for phase II trials, which were completed in 2015 for gastric cancer [200]. 


\section{CLEC14a Signaling}

\subsection{Overview}

CLEC14a (C-type lectin domain family 14 member) is a member of the C-type lectin/C-type lectin-like domain (CTL/CTLD) superfamily, which also includes thrombomodulin, CD93, and endosialin [202]. It is a type I transmembrane protein composed of a signal peptide (amino acids 1-22), an extracellular domain (amino acids 23-398) containing a CTLD, an EGF-like domain, a low compositional complexity region, a transmembrane domain (amino acids 399-421), and a cytosolic domain (422-490) [203]. In 2011, it was first reported that CLEC14a is expressed exclusively in endothelial cells, and plays a key role in endothelial migration, tube formation, and endothelial cell-cell contacts in angiogenesis [204]. In addition, we also reported that the CLEC14a CTLD is important for regulating filopodia formation and cell migration [205].

To date, several CLEC14a-binding partners, including multimerin 2 (MMRN2; endoglyx-1) and heat shock protein 70-1A (HSP70-1A), have been identified. MMRN2 is an extracellular matrix glycoprotein that suppresses angiogenesis via direct binding to VEGF-A, and binds the extracellular domain of CLEC14a [206]. Inhibition of CLEC14a-MMRN2 binding suppresses sprouting angiogenesis and tumor growth [207]. HSP70-1A is a molecular chaperone that stabilizes newly synthesized or misfolded proteins inside cells. We found that extracellular HSP70-1A binds to the CLEC14a CTLD on the surface of endothelial cells and promotes CLEC14a-CTLD-mediated endothelial cell-cell contacts, suggesting that extracellular HSP70-1A secreted from tumor cells may stabilize CLEC14a to stimulate endothelial cell-cell contacts in angiogenesis [208].

\subsection{Role and Relevance of CLEC14a in Cancer}

In 2012, Mura et al. first identified CLEC14a as a novel tumor endothelial marker protein in patient tissue samples [203]. CLEC14a is exclusively expressed on tumor blood vessels in various cancers, including ovarian, liver, bladder, breast, kidney, pancreas, stomach, and esophageal cancer, but not on normal blood vessels. In the same paper, using the ectopic expression and siRNA-mediated knockdown of CLEC14a, the authors showed that CLEC14a regulates angiogenic functions including filopodia formation, endothelial cell migration, and tube formation, demonstrating the importance of CLEC14a in tumor angiogenesis. Furthermore, their findings showed that the expression of CLEC14a is regulated by shear stress, suggesting that low shear stress at the tumor endothelial surface may be one of factors leading to CLEC14a expression on tumor vessels.

Interestingly, CLEC14a is also highly expressed on blood vessels in RIP-Tag2 insulinoma and HPV16/E2-induced invasive cervical cancer [209]. In addition, CLEC14A mRNA is highly upregulated in CD109+ circulating endothelial cells in breast cancer and glioblastoma patients [210]. Recently, Noy et al. reported that tumor growth and vascularity was reduced in a CLEC14a-knockout syngeneic tumor mouse model, compared to wild-type mice [207]. More recently, Krishna et al., reported that microvessel density, detected using an anti-CLEC14a antibody, was significantly reduced in patients with epithelial ovarian cancer treated with chemotherapy, suggesting that CLEC14a may be a more specific endothelial marker to assess tumor angiogenesis [211]. Collectively, this evidence suggests that CLEC14a may be a novel tumor endothelial cell-specific marker of tumor angiogenesis and a central regulator of tumor angiogenesis.

\subsection{Monoclonal Antibodies Targeting CLEC14a}

Mura et al. first provided the proof-of-concept that antibody-based modulation of CLEC14a may be effective for suppressing angiogenesis. They showed that CLEC14a polyclonal antibodies inhibit angiogenic functions, such as cell migration and tube formation, in vitro [203]. The same group also developed a mouse monoclonal antibody (C4 clone) that binds to CLEC14a and inhibits tube formation and sprouting angiogenesis in vitro and in vivo [207]. They also showed that the C4 clone suppressed tumor angiogenesis and tumor growth by blocking the interaction between MMRN2 and CLEC14a. 
However, the identification of the C4 epitope on CLEC14a and its immunogenicity for therapeutic use require further study.

Since the CTLD is an important domain for CLEC14a-induced angiogenesis, we selected it as a target antigen to generate human monoclonal antibodies from a human synthetic single antibody library using phage display technology. We generated a human monoclonal antibody targeting the CLEC14a CTLD that has cross-species reactivity for human and mouse CLEC14a, and potently inhibits cell-cell adhesion, endothelial migration, and tube formation [205]. In the same study, we also demonstrated that it acts as an interaction blockade to inhibit CLEC14a-CTLD-mediated cell-cell contacts by blocking the interaction between CTLDs. Additionally, CLEC14a cross-linking with the antibody induces internalization and downregulation of CLEC14a expression on the surface of endothelial cells to suppress angiogenesis.

Our recent results demonstrate that an optimized human monoclonal antibody targeting the CLEC14a CTLD inhibits VEGF-dependent tube formation in vitro, rat aorta vessel sprouting, and microvessel formation in vivo. In addition, it does not affect VEGF signaling on normal endothelial cells, which are associated with bevacizumab side effects. Furthermore, this antibody suppresses tumor angiogenesis in the in vivo angiogenesis mouse models of SNU182 hepatocellular carcinoma, CFPAC-1 pancreatic cancer, and U87 glioma cell lines. Interestingly, we also found that our antibody not only effectively suppresses tumor angiogenesis in the in vivo angiogenesis mouse models of HCT116 colorectal cancer cell lines, but also in those of bevacizumab-resistant HCT116-derived tumor cells, suggesting that antibody targeting of the CLEC14a CTLD may be an effective strategy to improve treatment options for bevacizumab-resistant tumors [212]. Together, these data suggest that CLEC14a is a novel therapeutic target for tumor angiogenesis, and that antibody-based targeting of CLEC14a may be an effective strategy for suppressing tumor angiogenesis.

\section{Conclusions}

For years, anti-angiogenesis strategies using monoclonal antibodies have been effective in suppressing tumor progression and metastasis in combination with chemotherapy. In particular, bevacizumab was a best-selling product among oncology products worldwide in 2016. This review discusses the role and relevance of VEGF and VEGFR and other anti-angiogenic targets in cancer and the developmental status of monoclonal antibodies against these targets. Although this review mainly covers emerging anti-angiogenic targets in cancers, further studies to identify novel therapeutic targets are still important for the better clinical outcome of cancer patients. Furthermore, the recent advent of the bevacizumab patent expiration will support the development of a variety of bevacizumab-like anti-angiogenic antibodies, which include bispecific antibodies that target VEGF, as well as monospecific antibodies to be used in combination with bevacizumab. In addition, for the continuous improvement of patient survival and quality of life, the next-generation anti-angiogenic therapeutic antibodies must overcome the unmet medical needs of bevacizumab in terms of its adverse effects and drug resistance.

Acknowledgments: This work was supported by grants from the Scripps Korea Antibody Institute (10TS03) and the Bio \& Medical Technology Development Program of the National Research Foundation (NRF) funded by the Korean government (MSIP) (2015M3A9 D9074279). The authors apologize to those investigators whose experimental work has been cited indirectly in this article because of space limitations.

Author Contributions: Deok-Hoon Kong, Mi Ra Kim, and Ji Hye Jang collected all the information and wrote the manuscript. Hee-Jun Na and Sukmook Lee supervised the project and wrote the paper. All authors discussed and commented on the manuscript.

Conflicts of Interest: The authors declare no conflict of interest. 


\section{Abbreviations}

$\begin{array}{ll}\text { Ang } & \text { Angiopoietin } \\ \text { CLEC14a } & \text { C-type domain family 14 member } \\ \text { CTLD } & \text { C-type lectin-like domain } \\ \text { HGF } & \text { Hepatocyte growth factor } \\ \text { Ig } & \text { Immunoglobulin } \\ \text { PDGF } & \text { Platelet-derived growth factor } \\ \text { Tie } & \text { Tyrosine kinase with Ig-like and EGF-like } \\ \text { VEGF } & \text { Vascular endothelial growth factor }\end{array}$

\section{References}

1. Li, B.; Xiu, R. Angiogenesis: From molecular mechanisms to translational implications. Clin. Hemorheol. Microcirc. 2013, 54, 345-355. [PubMed]

2. Papetti, M.; Herman, I.M. Mechanisms of normal and tumor-derived angiogenesis. Am. J. Physiol. Cell Physiol. 2002, 282, C947-C970. [CrossRef] [PubMed]

3. DiPietro, L.A. Angiogenesis and wound repair: When enough is enough. J. Leukoc. Biol. 2016, 100, 979-984. [CrossRef] [PubMed]

4. Potente, M.; Gerhardt, H.; Carmeliet, P. Basic and therapeutic aspects of angiogenesis. Cell 2011, 146, $873-887$. [CrossRef] [PubMed]

5. Leung, D.W.; Cachianes, G.; Kuang, W.J.; Goeddel, D.V.; Ferrara, N. Vascular endothelial growth factor is a secreted angiogenic mitogen. Science 1989, 246, 1306-1309. [CrossRef] [PubMed]

6. Millauer, B.; Wizigmann-Voos, S.; Schnurch, H.; Martinez, R.; Moller, N.P.; Risau, W.; Ullrich, A. High affinity VEGF binding and developmental expression suggest Flk-1 as a major regulator of vasculogenesis and angiogenesis. Cell 1993, 72, 835-846. [CrossRef]

7. Battegay, E.J.; Rupp, J.; Iruela-Arispe, L.; Sage, E.H.; Pech, M. PDGF-BB modulates endothelial proliferation and angiogenesis in vitro via PDGF $\beta$-receptors. J. Cell Biol. 1994, 125, 917-928. [CrossRef] [PubMed]

8. Suri, C.; Jones, P.F.; Patan, S.; Bartunkova, S.; Maisonpierre, P.C.; Davis, S.; Sato, T.N.; Yancopoulos, G.D. Requisite role of angiopoietin-1, a ligand for the Tie2 receptor, during embryonic angiogenesis. Cell 1996, 87, 1171-1180. [CrossRef]

9. Rosen, E.M.; Grant, D.S.; Kleinman, H.K.; Goldberg, I.D.; Bhargava, M.M.; Nickoloff, B.J.; Kinsella, J.L.; Polverini, P. Scatter factor (hepatocyte growth factor) is a potent angiogenesis factor in vivo. Symp. Soc. Exp. Biol. 1993, 47, 227-234. [PubMed]

10. Taniguchi, E.; Nagae, Y.; Watanabe, H.; Ohashi, Y.; Kinoshita, S.; Manabe, R. The effect of recombinant epidermal growth factor in corneal angiogenesis. Nippon Ganka Gakkai Zasshi 1991, 95, 52-58. [PubMed]

11. Folkman, J.; Browder, T.; Palmblad, J. Angiogenesis research: Guidelines for translation to clinical application. Thromb. Haemost. 2001, 86, 23-33. [PubMed]

12. Hanahan, D.; Weinberg, R.A. Hallmarks of cancer: The next generation. Cell 2011, 144, 646-674. [CrossRef] [PubMed]

13. Gabrilove, J.L. Angiogenic growth factors: Autocrine and paracrine regulation of survival in hematologic malignancies. Oncologist 2001, 6 (Suppl. S5), 4-7. [CrossRef] [PubMed]

14. Hoeben, A.; Landuyt, B.; Highley, M.S.; Wildiers, H.; Van Oosterom, A.T.; De Bruijn, E.A. Vascular endothelial growth factor and angiogenesis. Pharmacol. Rev. 2004, 56, 549-580. [CrossRef] [PubMed]

15. Jain, R.K. Tumor angiogenesis and accessibility: Role of vascular endothelial growth factor. Semin. Oncol. 2002, 29, 3-9. [CrossRef] [PubMed]

16. Ferrara, N.; Hillan, K.J.; Gerber, H.P.; Novotny, W. Discovery and development of bevacizumab, an anti-VEGF antibody for treating cancer. Nat. Rev. Drug Discov. 2004, 3, 391-400. [CrossRef] [PubMed]

17. Culy, C. Bevacizumab: Antiangiogenic cancer therapy. Drugs Today 2005, 41, 23-36. [CrossRef] [PubMed]

18. Arriaga, Y.; Becerra, C.R. Adverse effects of bevacizumab and their management in solid tumors. Support. Cancer Ther. 2006, 3, 247-250. [CrossRef] [PubMed]

19. Gordon, M.S.; Cunningham, D. Managing patients treated with bevacizumab combination therapy. Oncology 2005, 69 (Suppl 3), 25-33. [CrossRef] [PubMed] 
20. Lucio-Eterovic, A.K.; Piao, Y.; de Groot, J.F. Mediators of glioblastoma resistance and invasion during antivascular endothelial growth factor therapy. Clin. Cancer Res. 2009, 15, 4589-4599. [CrossRef] [PubMed]

21. de Groot, J.F.; Fuller, G.; Kumar, A.J.; Piao, Y.; Eterovic, K.; Ji, Y.; Conrad, C.A. Tumor invasion after treatment of glioblastoma with bevacizumab: Radiographic and pathologic correlation in humans and mice. Neuro-Oncology 2010, 12, 233-242. [CrossRef] [PubMed]

22. Furuta, T.; Nakada, M.; Misaki, K.; Sato, Y.; Hayashi, Y.; Nakanuma, Y.; Hamada, J. Molecular analysis of a recurrent glioblastoma treated with bevacizumab. Brain Tumor Pathol. 2014, 31, 32-39. [CrossRef] [PubMed]

23. Scholz, A.; Harter, P.N.; Cremer, S.; Yalcin, B.H.; Gurnik, S.; Yamaji, M.; Di Tacchio, M.; Sommer, K.; Baumgarten, P.; Bahr, O.; et al. Endothelial cell-derived angiopoietin-2 is a therapeutic target in treatment-naive and bevacizumab-resistant glioblastoma. EMBO Mol. Med. 2016, 8, 39-57. [CrossRef] [PubMed]

24. Sathornsumetee, S.; Rich, J.N. Antiangiogenic therapy in malignant glioma: Promise and challenge. Curr. Pharm. Des. 2007, 13, 3545-3558. [CrossRef] [PubMed]

25. Giuliano, S.; Pages, G. Mechanisms of resistance to anti-angiogenesis therapies. Biochimie 2013, 95, 1110-1119. [CrossRef] [PubMed]

26. Kliche, S.; Waltenberger, J. VEGF receptor signaling and endothelial function. IUBMB Life 2001, 52, 61-66. [CrossRef] [PubMed]

27. Woolard, J.; Bevan, H.S.; Harper, S.J.; Bates, D.O. Molecular diversity of VEGF-A as a regulator of its biological activity. Microcirculation 2009, 16, 572-592. [CrossRef] [PubMed]

28. Ferrara, N.; Henzel, W.J. Pituitary follicular cells secrete a novel heparin-binding growth factor specific for vascular endothelial cells. Biochem. Biophys. Res. Commun. 1989, 161, 851-858. [CrossRef]

29. Shibuya, M. Vascular endothelial growth factor (VEGF) and its receptor (VEGFR) signaling in angiogenesis: A crucial target for anti- and pro-angiogenic therapies. Genes Cancer 2011, 2, 1097-1105. [CrossRef] [PubMed]

30. Muller, Y.A.; Li, B.; Christinger, H.W.; Wells, J.A.; Cunningham, B.C.; De Vos, A.M. Vascular endothelial growth factor: Crystal structure and functional mapping of the kinase domain receptor binding site. Proc. Natl. Acad. Sci. USA 1997, 94, 7192-7197. [CrossRef] [PubMed]

31. Koch, S.; Claesson-Welsh, L. Signal transduction by vascular endothelial growth factor receptors. Cold Spring Harb. Perspect. Med. 2012, 2, a006502. [CrossRef] [PubMed]

32. Olsson, A.K.; Dimberg, A.; Kreuger, J.; Claesson-Welsh, L. VEGF receptor signalling-In control of vascular function. Nat. Rev. Mol. Cell Biol. 2006, 7, 359-371. [CrossRef] [PubMed]

33. Li, X. VEGF-B: A thing of beauty. Cell Res. 2010, 20, 741-744. [CrossRef] [PubMed]

34. De Falco, S. The discovery of placenta growth factor and its biological activity. Exp. Mol. Med. 2012, 44, 1-9. [CrossRef] [PubMed]

35. Smith, G.A.; Fearnley, G.W.; Tomlinson, D.C.; Harrison, M.A.; Ponnambalam, S. The cellular response to vascular endothelial growth factors requires co-ordinated signal transduction, trafficking and proteolysis. Biosci. Rep. 2015, 35. [CrossRef] [PubMed]

36. Wang, F.; Yamauchi, M.; Muramatsu, M.; Osawa, T.; Tsuchida, R.; Shibuya, M. Rack1 regulates VEGF/FLT1-mediated cell migration via activation of a PI3K/Akt pathway. J. Biol. Chem. 2011, 286, 9097-9106. [CrossRef] [PubMed]

37. Cai, J.; Ahmad, S.; Jiang, W.G.; Huang, J.; Kontos, C.D.; Boulton, M.; Ahmed, A. Activation of vascular endothelial growth factor receptor-1 sustains angiogenesis and BCL-2 expression via the phosphatidylinositol 3-kinase pathway in endothelial cells. Diabetes 2003, 52, 2959-2968. [CrossRef] [PubMed]

38. Tchaikovski, V.; Fellbrich, G.; Waltenberger, J. The molecular basis of VEGFR-1 signal transduction pathways in primary human monocytes. Arterioscler. Thromb. Vasc. Biol. 2008, 28, 322-328. [CrossRef] [PubMed]

39. Simons, M.; Gordon, E.; Claesson-Welsh, L. Mechanisms and regulation of endothelial VEGF receptor signalling. Nat. Rev. Mol. Cell Biol. 2016, 17, 611-625. [CrossRef] [PubMed]

40. Matsumoto, T.; Bohman, S.; Dixelius, J.; Berge, T.; Dimberg, A.; Magnusson, P.; Wang, L.; Wikner, C.; Qi, J.H.; Wernstedt, C.; et al. VEGF receptor-2 Y951 signaling and a role for the adapter molecule TSAd in tumor angiogenesis. EMBO J. 2005, 24, 2342-2353. [CrossRef] [PubMed]

41. Salameh, A.; Galvagni, F.; Bardelli, M.; Bussolino, F.; Oliviero, S. Direct recruitment of CRK and GRB2 to VEGFR-3 induces proliferation, migration, and survival of endothelial cells through the activation of Erk, Akt, and Jnk pathways. Blood 2005, 106, 3423-3431. [CrossRef] [PubMed] 
42. Deng, Y.; Zhang, X.; Simons, M. Molecular controls of lymphatic VEGFR3 signaling. Arterioscler. Thromb. Vasc. Biol. 2015, 35, 421-429. [CrossRef] [PubMed]

43. Jiang, B.H.; Liu, L.Z. PI3K/PTEN signaling in angiogenesis and tumorigenesis. Adv. Cancer Res. 2009, 102, 19-65. [CrossRef] [PubMed]

44. Goel, H.L.; Mercurio, A.M. VEGF targets the tumour cell. Nat. Rev. Cancer 2013, 13, 871-882. [CrossRef] [PubMed]

45. Lee, S.H.; Jeong, D.; Han, Y.S.; Baek, M.J. Pivotal role of vascular endothelial growth factor pathway in tumor angiogenesis. Ann. Surg. Treat. Res. 2015, 89, 1-8. [CrossRef] [PubMed]

46. Shweiki, D.; Itin, A.; Soffer, D.; Keshet, E. Vascular endothelial growth factor induced by hypoxia may mediate hypoxia-initiated angiogenesis. Nature 1992, 359, 843-845. [CrossRef] [PubMed]

47. Levy, A.P.; Levy, N.S.; Goldberg, M.A. Post-transcriptional regulation of vascular endothelial growth factor by hypoxia. J. Biol. Chem. 1996, 271, 2746-2753. [CrossRef] [PubMed]

48. Song, G.; Li, Y.; Jiang, G. Role of VEGF/VEGFR in the pathogenesis of leukemias and as treatment targets (review). Oncol. Rep. 2012, 28, 1935-1944. [PubMed]

49. Yang, Y.; Bai, Y.; Xie, G.; Zhang, N.; Ma, Y.P.; Chen, L.J.; Jiang, Y.; Zhao, X.; Wei, Y.Q.; Deng, H.X. Efficient inhibition of non-small-cell lung cancer xenograft by systemic delivery of plasmid-encoding short-hairpin rna targeting vegf. Cancer Biother. Radiopharm. 2010, 25, 65-73. [CrossRef] [PubMed]

50. Liang, Y.; Brekken, R.A.; Hyder, S.M. Vascular endothelial growth factor induces proliferation of breast cancer cells and inhibits the anti-proliferative activity of anti-hormones. Endocr. Relat. Cancer 2006, 13, 905-919. [CrossRef] [PubMed]

51. Wang, X.; Chen, X.; Fang, J.; Yang, C. Overexpression of both VEGF-A and VEGF-C in gastric cancer correlates with prognosis, and silencing of both is effective to inhibit cancer growth. Int. J. Clin. Exp. Pathol. 2013, 6, 586-597. [PubMed]

52. Ohta, Y.; Endo, Y.; Tanaka, M.; Shimizu, J.; Oda, M.; Hayashi, Y.; Watanabe, Y.; Sasaki, T. Significance of vascular endothelial growth factor messenger RNA expression in primary lung cancer. Clin. Cancer Res. 1996, 2, 1411-1416. [PubMed]

53. Lu, L.; Luo, S.T.; Shi, H.S.; Li, M.; Zhang, H.L.; He, S.S.; Liu, Y.; Pan, Y.; Yang, L. Aav2-mediated gene transfer of VEGF-trap with potent suppression of primary breast tumor growth and spontaneous pulmonary metastases by long-term expression. Oncol. Rep. 2012, 28, 1332-1338. [PubMed]

54. Zins, K.; Kovatchki, D.; Lucas, T.; Abraham, D. PLGF and VEGF-A regulate growth of high-risk MYCN-single copy neuroblastoma xenografts via different mechanisms. Int. J. Mol. Sci. 2016, 17, 1613. [CrossRef] [PubMed]

55. De Brot, S.; Ntekim, A.; Cardenas, R.; James, V.; Allegrucci, C.; Heery, D.M.; Bates, D.O.; Odum, N.; Persson, J.L.; Mongan, N.P. Regulation of vascular endothelial growth factor in prostate cancer. Endocr. Relat. Cancer 2015, 22, R107-R123. [CrossRef] [PubMed]

56. Cao, G.; Li, X.; Qin, C.; Li, J. Prognostic value of VEGF in hepatocellular carcinoma patients treated with sorafenib: A meta-analysis. Med. Sci. Monit. 2015, 21, 3144-3151. [CrossRef] [PubMed]

57. Wang, S.; Jia, M. Antibody therapies in cancer. Adv. Exp. Med. Biol. 2016, 909, 1-67. [PubMed]

58. Andreakos, E.; Taylor, P.C.; Feldmann, M. Monoclonal antibodies in immune and inflammatory diseases. Curr. Opin. Biotechnol. 2002, 13, 615-620. [CrossRef]

59. Martin, D.F.; Maguire, M.G.; Ying, G.S.; Grunwald, J.E.; Fine, S.L.; Jaffe, G.J. Ranibizumab and bevacizumab for neovascular age-related macular degeneration. N. Engl. J. Med. 2011, 364, 1897-1908. [CrossRef] [PubMed]

60. Ecker, D.M.; Jones, S.D.; Levine, H.L. The therapeutic monoclonal antibody market. $m A b s$ 2015, 7, 9-14. [CrossRef] [PubMed]

61. Braghiroli, M.I.; Sabbaga, J.; Hoff, P.M. Bevacizumab: Overview of the literature. Expert Rev. Anticancer Ther. 2012, 12, 567-580. [CrossRef] [PubMed]

62. Ellis, L.M. Bevacizumab. Nat. Rev. Drug Discov. 2005, 4, S8-S9. [CrossRef]

63. Cohen, M.H.; Shen, Y.L.; Keegan, P.; Pazdur, R. Fda drug approval summary: Bevacizumab (avastin) as treatment of recurrent glioblastoma multiforme. Oncologist 2009, 14, 1131-1138. [CrossRef] [PubMed]

64. Planchard, D. Bevacizumab in non-small-cell lung cancer: A review. Expert Rev. Anticancer Ther. 2011, 11, 1163-1179. [CrossRef] [PubMed] 
65. Rinne, M.L.; Lee, E.Q.; Nayak, L.; Norden, A.D.; Beroukhim, R.; Wen, P.Y.; Reardon, D.A. Update on bevacizumab and other angiogenesis inhibitors for brain cancer. Expert Opin. Emerg. Drugs 2013, 18, $137-153$. [CrossRef] [PubMed]

66. Shih, T.; Lindley, C. Bevacizumab: An angiogenesis inhibitor for the treatment of solid malignancies. Clin. Ther. 2006, 28, 1779-1802. [CrossRef] [PubMed]

67. Garcia, A.; Singh, H. Bevacizumab and ovarian cancer. Ther. Adv. Med. Oncol. 2013, 5, 133-141. [CrossRef] [PubMed]

68. Al-Halafi, A.M. Vascular endothelial growth factor trap-eye and trap technology: Aflibercept from bench to bedside. Oman J. Ophthalmol. 2014, 7, 112-115. [CrossRef] [PubMed]

69. Andre, T.; Chibaudel, B. Aflibercept (zaltrap ()) approved in metastatic colorectal cancer. Bull Cancer 2013, 100, 1023-1025. [PubMed]

70. Sarwar, S.; Clearfield, E.; Soliman, M.K.; Sadiq, M.A.; Baldwin, A.J.; Hanout, M.; Agarwal, A.; Sepah, Y.J.; Do, D.V.; Nguyen, Q.D. Aflibercept for neovascular age-related macular degeneration. Cochrane Database Syst. Rev. 2016, 2, CD011346. [PubMed]

71. Ashraf, M.; Souka, A.A.R. Aflibercept in age-related macular degeneration: Evaluating its role as a primary therapeutic option. Eye 2017. [CrossRef] [PubMed]

72. Moreno, T.A.; Kim, S.J. Ranibizumab (lucentis) versus bevacizumab (avastin) for the treatment of age-related macular degeneration: An economic disparity of eye health. Semin. Ophthalmol. 2016, 31, 378-384. [CrossRef] [PubMed]

73. Bevacizumab (avastin) and age-related macular degeneration. Lower cost does not justify taking risks. Prescrire Int. 2015, 24, 201-204.

74. Spratlin, J.L.; Mulder, K.E.; Mackey, J.R. Ramucirumab (IMC-1121B): A novel attack on angiogenesis. Future Oncol. 2010, 6, 1085-1094. [CrossRef] [PubMed]

75. Spratlin, J. Ramucirumab (imc-1121b): Monoclonal antibody inhibition of vascular endothelial growth factor receptor-2. Curr. Oncol. Rep. 2011, 13, 97-102. [CrossRef] [PubMed]

76. Takeda, K.; Daga, H. Ramucirumab for the treatment of advanced or metastatic non-small cell lung cancer. Expert Opin. Biol. Ther. 2016, 16, 1541-1547. [CrossRef] [PubMed]

77. Poole, R.M.; Vaidya, A. Ramucirumab: First global approval. Drugs 2014, 74, 1047-1058. [CrossRef] [PubMed]

78. Arrieta, O.; Zatarain-Barron, Z.L.; Cardona, A.F.; Carmona, A.; Lopez-Mejia, M. Ramucirumab in the treatment of non-small cell lung cancer. Expert Opin. Drug Saf. 2017, 16, 637-644. [CrossRef] [PubMed]

79. Zhu, A.X.; Park, J.O.; Ryoo, B.Y.; Yen, C.J.; Poon, R.; Pastorelli, D.; Blanc, J.F.; Chung, H.C.; Baron, A.D.; Pfiffer, T.E.; et al. Ramucirumab versus placebo as second-line treatment in patients with advanced hepatocellular carcinoma following first-line therapy with sorafenib (reach): A randomised, double-blind, multicentre, phase 3 trial. Lancet Oncol. 2015, 16, 859-870. [CrossRef]

80. Mackey, J.R.; Ramos-Vazquez, M.; Lipatov, O.; McCarthy, N.; Krasnozhon, D.; Semiglazov, V.; Manikhas, A.; Gelmon, K.A.; Konecny, G.E.; Webster, M.; et al. Primary results of ROSE/TRIO-12, a randomized placebo-controlled phase III trial evaluating the addition of ramucirumab to first-line docetaxel chemotherapy in metastatic breast cancer. J. Clin. Oncol. 2015, 33, 141-148. [CrossRef] [PubMed]

81. Petrylak, D.P.; Tagawa, S.T.; Kohli, M.; Eisen, A.; Canil, C.; Sridhar, S.S.; Spira, A.; Yu, E.Y.; Burke, J.M.; Shaffer, D.; et al. Docetaxel as monotherapy or combined with ramucirumab or icrucumab in second-line treatment for locally advanced or metastatic urothelial carcinoma: An open-label, three-arm, randomized controlled phase II trial. J. Clin. Oncol. 2016, 34, 1500-1509. [CrossRef] [PubMed]

82. Lee, S.H. Tanibirumab (ttac-0001): A fully human monoclonal antibody targets vascular endothelial growth factor receptor 2 (VEGFR-2). Arch. Pharm. Res. 2011, 34, 1223-1226. [CrossRef] [PubMed]

83. Lee, S.J.; Lee, S.Y.; Lee, W.S.; Yoo, J.S.; Sun, J.M.; Lee, J.; Park, S.H.; Park, J.O.; Ahn, M.J.; Lim, H.Y.; et al. Phase I trial and pharmacokinetic study of tanibirumab, a fully human monoclonal antibody to vascular endothelial growth factor receptor 2, in patients with refractory solid tumors. Investig. New Drugs 2017. [CrossRef] [PubMed]

84. Raica, M.; Cimpean, A.M. Platelet-derived growth factor (PDGF)/PDGF receptors (PDGFR) axis as target for antitumor and antiangiogenic therapy. Pharmaceuticals 2010, 3, 572-599. [CrossRef] [PubMed]

85. Paul, D.; Lipton, A.; Klinger, I. Serum factor requirements of normal and simian virus 40-transformed 3T3 mouse fibroplasts. Proc. Natl. Acad. Sci. USA 1971, 68, 645-652. [CrossRef] [PubMed] 
86. Ek, B.; Heldin, C.H. Characterization of a tyrosine-specific kinase activity in human fibroblast membranes stimulated by platelet-derived growth factor. J. Biol. Chem. 1982, 257, 10486-10492. [PubMed]

87. Heldin, C.H. Targeting the pdgf signaling pathway in tumor treatment. Cell Commun. Signal. 2013, 11, 97. [CrossRef] [PubMed]

88. Shim, A.H.; Liu, H.; Focia, P.J.; Chen, X.; Lin, P.C.; He, X. Structures of a platelet-derived growth factor/propeptide complex and a platelet-derived growth factor/receptor complex. Proc. Natl. Acad. Sci. USA 2010, 107, 11307-11312. [CrossRef] [PubMed]

89. Chen, P.H.; Chen, X.; He, X. Platelet-derived growth factors and their receptors: Structural and functional perspectives. Biochim. Biophys. Acta 2013, 1834, 2176-2186. [CrossRef] [PubMed]

90. Fredriksson, L.; Li, H.; Eriksson, U. The pdgf family: Four gene products form five dimeric isoforms. Cytokine Growth Factor Rev. 2004, 15, 197-204. [CrossRef] [PubMed]

91. Omura, T.; Heldin, C.H.; Ostman, A. Immunoglobulin-like domain 4-mediated receptor-receptor interactions contribute to platelet-derived growth factor-induced receptor dimerization. J. Biol. Chem. 1997, 272, 12676-12682. [CrossRef] [PubMed]

92. Yang, Y.; Yuzawa, S.; Schlessinger, J. Contacts between membrane proximal regions of the PDGF receptor ectodomain are required for receptor activation but not for receptor dimerization. Proc. Natl. Acad. Sci. USA 2008, 105, 7681-7686. [CrossRef] [PubMed]

93. Andrae, J.; Gallini, R.; Betsholtz, C. Role of platelet-derived growth factors in physiology and medicine. Genes Dev. 2008, 22, 1276-1312. [CrossRef] [PubMed]

94. Franke, T.F.; Yang, S.I.; Chan, T.O.; Datta, K.; Kazlauskas, A.; Morrison, D.K.; Kaplan, D.R.; Tsichlis, P.N. The protein kinase encoded by the Akt proto-oncogene is a target of the PDGF-activated phosphatidylinositol 3-kinase. Cell 1995, 81, 727-736. [CrossRef]

95. Akimoto, K.; Takahashi, R.; Moriya, S.; Nishioka, N.; Takayanagi, J.; Kimura, K.; Fukui, Y.; Osada, S.; Mizuno, K.; Hirai, S.; et al. EGF or PDGF receptors activate atypical pkclambda through phosphatidylinositol 3-kinase. EMBO J. 1996, 15, 788-798. [PubMed]

96. Chung, J.; Grammer, T.C.; Lemon, K.P.; Kazlauskas, A.; Blenis, J. PDGF- and insulin-dependent pp70s6k activation mediated by phosphatidylinositol-3-OH kinase. Nature 1994, 370, 71-75. [CrossRef] [PubMed]

97. Lopez-Ilasaca, M.; Li, W.; Uren, A.; Yu, J.C.; Kazlauskas, A.; Gutkind, J.S.; Heidaran, M.A. Requirement of phosphatidylinositol-3 kinase for activation of JNK/SAPKs by PDGF. Biochem. Biophys. Res. Commun. 1997, 232, 273-277. [CrossRef] [PubMed]

98. Hawkins, P.T.; Eguinoa, A.; Qiu, R.G.; Stokoe, D.; Cooke, F.T.; Walters, R.; Wennstrom, S.; Claesson-Welsh, L.; Evans, T.; Symons, M.; et al. PDGF stimulates an increase in GTP-Rac via activation of phosphoinositide 3-kinase. Curr. Biol. 1995, 5, 393-403. [CrossRef]

99. Li, W.L.; Yamada, Y.; Ueno, M.; Nishikawa, S.; Takakura, N. Platelet derived growth factor receptor $\alpha$ is essential for establishing a microenvironment that supports definitive erythropoiesis. J. Biochem. 2006, 140, 267-273. [CrossRef] [PubMed]

100. Pierce, G.F.; Mustoe, T.A.; Altrock, B.W.; Deuel, T.F.; Thomason, A. Role of platelet-derived growth factor in wound healing. J. Cell Biochem. 1991, 45, 319-326. [CrossRef] [PubMed]

101. Ataliotis, P.; Mercola, M. Distribution and functions of platelet-derived growth factors and their receptors during embryogenesis. Int. Rev. Cytol. 1997, 172, 95-127. [PubMed]

102. Caplan, A.I.; Correa, D. PDGF in bone formation and regeneration: New insights into a novel mechanism involving MSCS. J. Orthop. Res. 2011, 29, 1795-1803. [CrossRef] [PubMed]

103. Board, R.; Jayson, G.C. Platelet-derived growth factor receptor (PDGFR): A target for anticancer therapeutics. Drug Resist. Updates 2005, 8, 75-83. [CrossRef] [PubMed]

104. Cao, R.; Brakenhielm, E.; Li, X.; Pietras, K.; Widenfalk, J.; Ostman, A.; Eriksson, U.; Cao, Y. Angiogenesis stimulated by PDGF-CC, a novel member in the PDGF family, involves activation of PDGFR- $\alpha \alpha$ and $-\alpha \beta$ receptors. FASEB J. 2002, 16, 1575-1583. [CrossRef] [PubMed]

105. Li, X.; Ponten, A.; Aase, K.; Karlsson, L.; Abramsson, A.; Uutela, M.; Backstrom, G.; Hellstrom, M.; Bostrom, H.; Li, H.; et al. PDGF-c is a new protease-activated ligand for the PDGF $\alpha$-receptor. Nat. Cell Biol. 2000, 2, 302-309. [PubMed]

106. Li, X.; Kumar, A.; Zhang, F.; Lee, C.; Li, Y.; Tang, Z.; Arjuna, P. VEGF-independent angiogenic pathways induced by PDGF-c. Oncotarget 2010, 1, 309-314. [CrossRef] [PubMed] 
107. Uutela, M.; Wirzenius, M.; Paavonen, K.; Rajantie, I.; He, Y.; Karpanen, T.; Lohela, M.; Wiig, H.; Salven, P.; Pajusola, K.; et al. PDGF-d induces macrophage recruitment, increased interstitial pressure, and blood vessel maturation during angiogenesis. Blood 2004, 104, 3198-3204. [CrossRef] [PubMed]

108. Kumar, A.; Hou, X.; Lee, C.; Li, Y.; Maminishkis, A.; Tang, Z.; Zhang, F.; Langer, H.F.; Arjunan, P.; Dong, L.; et al. Platelet-derived growth factor-DD targeting arrests pathological angiogenesis by modulating glycogen synthase kinase-3 $\beta$ phosphorylation. J. Biol. Chem. 2010, 285, 15500-15510. [CrossRef] [PubMed]

109. Manzat Saplacan, R.M.; Balacescu, L.; Gherman, C.; Chira, R.I.; Craiu, A.; Mircea, P.A.; Lisencu, C.; Balacescu, O. The role of PDGFs and PDGFRs in colorectal cancer. Mediat. Inflamm. 2017, 2017, 4708076. [CrossRef] [PubMed]

110. Di Tomaso, E.; London, N.; Fuja, D.; Logie, J.; Tyrrell, J.A.; Kamoun, W.; Munn, L.L.; Jain, R.K. PDGF-c induces maturation of blood vessels in a model of glioblastoma and attenuates the response to anti-VEGF treatment. PLoS ONE 2009, 4, e5123. [CrossRef] [PubMed]

111. Park, Y.H.; Seo, S.Y.; Ha, M.; Ku, J.H.; Kim, H.H.; Kwak, C. Inhibition of prostate cancer using RNA interference-directed knockdown of platelet-derived growth factor receptor. Urology 2011, 77, e1509-e1515. [CrossRef] [PubMed]

112. Gotzmann, J.; Fischer, A.N.; Zojer, M.; Mikula, M.; Proell, V.; Huber, H.; Jechlinger, M.; Waerner, T.; Weith, A.; Beug, H.; et al. A crucial function of PDGF in TGF- $\beta$-mediated cancer progression of hepatocytes. Oncogene 2006, 25, 3170-3185. [CrossRef] [PubMed]

113. Devarajan, E.; Song, Y.H.; Krishnappa, S.; Alt, E. Epithelial-mesenchymal transition in breast cancer lines is mediated through PDGF-d released by tissue-resident stem cells. Int. J. Cancer 2012, 131, 1023-1031. [CrossRef] [PubMed]

114. De Falco, S. Antiangiogenesis therapy: An update after the first decade. Korean J. Intern. Med. 2014, $29,1-11$. [CrossRef] [PubMed]

115. Loizos, N.; Xu, Y.; Huber, J.; Liu, M.; Lu, D.; Finnerty, B.; Rolser, R.; Malikzay, A.; Persaud, A.; Corcoran, E.; et al. Targeting the platelet-derived growth factor receptor alpha with a neutralizing human monoclonal antibody inhibits the growth of tumor xenografts: Implications as a potential therapeutic target. Mol. Cancer Ther. 2005, 4, 369-379. [PubMed]

116. Wagner, A.J.; Kindler, H.; Gelderblom, H.; Schoffski, P.; Bauer, S.; Hohenberger, P.; Kopp, H.G.; Lopez-Martin, J.A.; Peeters, M.; Reichardt, P.; et al. A phase II study of a human anti-PDGFR $\alpha$ monoclonal antibody (olaratumab, IMC-3G3) in previously treated patients with metastatic gastrointestinal stromal tumors. Ann. Oncol. 2017, 28, 541-546. [CrossRef] [PubMed]

117. Russell, M.R.; Liu, Q.; Fatatis, A. Targeting the $\alpha$ receptor for platelet-derived growth factor as a primary or combination therapy in a preclinical model of prostate cancer skeletal metastasis. Clin. Cancer Res. 2010, 16, 5002-5010. [CrossRef] [PubMed]

118. Chiorean, E.G.; Sweeney, C.; Youssoufian, H.; Qin, A.; Dontabhaktuni, A.; Loizos, N.; Nippgen, J.; Amato, R. A phase I study of olaratumab, an anti-platelet-derived growth factor receptor $\alpha$ (PDGFR $\alpha$ ) monoclonal antibody, in patients with advanced solid tumors. Cancer Chemother. Pharmacol. 2014, 73, 595-604. [CrossRef] [PubMed]

119. Tap, W.D.; Jones, R.L.; Van Tine, B.A.; Chmielowski, B.; Elias, A.D.; Adkins, D.; Agulnik, M.; Cooney, M.M.; Livingston, M.B.; Pennock, G.; et al. Olaratumab and doxorubicin versus doxorubicin alone for treatment of soft-tissue sarcoma: An open-label phase $1 \mathrm{~b}$ and randomised phase 2 trial. Lancet 2016, 388, 488-497. [CrossRef]

120. Brindle, N.P.; Saharinen, P.; Alitalo, K. Signaling and functions of angiopoietin-1 in vascular protection. Circ. Res. 2006, 98, 1014-1023. [CrossRef] [PubMed]

121. Fagiani, E.; Christofori, G. Angiopoietins in angiogenesis. Cancer Lett. 2013, 328, 18-26. [CrossRef] [PubMed]

122. Davis, S.; Aldrich, T.H.; Jones, P.F.; Acheson, A.; Compton, D.L.; Jain, V.; Ryan, T.E.; Bruno, J.; Radziejewski, C.; Maisonpierre, P.C.; et al. Isolation of angiopoietin-1, a ligand for the Tie2 receptor, by secretion-trap expression cloning. Cell 1996, 87, 1161-1169. [CrossRef]

123. Maisonpierre, P.C.; Suri, C.; Jones, P.F.; Bartunkova, S.; Wiegand, S.J.; Radziejewski, C.; Compton, D.; McClain, J.; Aldrich, T.H.; Papadopoulos, N.; et al. Angiopoietin-2, a natural antagonist for Tie2 that disrupts in vivo angiogenesis. Science 1997, 277, 55-60. [CrossRef] [PubMed] 
124. Valenzuela, D.M.; Griffiths, J.A.; Rojas, J.; Aldrich, T.H.; Jones, P.F.; Zhou, H.; McClain, J.; Copeland, N.G.; Gilbert, D.J.; Jenkins, N.A.; et al. Angiopoietins 3 and 4: Diverging gene counterparts in mice and humans. Proc. Natl. Acad. Sci. USA 1999, 96, 1904-1909. [CrossRef] [PubMed]

125. Saharinen, P.; Kerkela, K.; Ekman, N.; Marron, M.; Brindle, N.; Lee, G.M.; Augustin, H.; Koh, G.Y.; Alitalo, K. Multiple angiopoietin recombinant proteins activate the Tie1 receptor tyrosine kinase and promote its interaction with Tie2. J. Cell Biol. 2005, 169, 239-243. [CrossRef] [PubMed]

126. Marron, M.B.; Hughes, D.P.; Edge, M.D.; Forder, C.L.; Brindle, N.P. Evidence for heterotypic interaction between the receptor tyrosine kinases Tie-1 and Tie-2. J. Biol. Chem. 2000, 275, 39741-39746. [CrossRef] [PubMed]

127. Thomas, M.; Augustin, H.G. The role of the angiopoietins in vascular morphogenesis. Angiogenesis 2009, 12, 125-137. [CrossRef] [PubMed]

128. Thurston, G. Role of angiopoietins and tie receptor tyrosine kinases in angiogenesis and lymphangiogenesis. Cell Tissue Res. 2003, 314, 61-68. [CrossRef] [PubMed]

129. Fiedler, U.; Krissl, T.; Koidl, S.; Weiss, C.; Koblizek, T.; Deutsch, U.; Martiny-Baron, G.; Marme, D.; Augustin, H.G. Angiopoietin-1 and angiopoietin-2 share the same binding domains in the Tie-2 receptor involving the first Ig-like loop and the epidermal growth factor-like repeats. J. Biol. Chem. 2003, 278, 1721-1727. [CrossRef] [PubMed]

130. Khan, A.A.; Sandhya, V.K.; Singh, P.; Parthasarathy, D.; Kumar, A.; Advani, J.; Gattu, R.; Ranjit, D.V.; Vaidyanathan, R.; Mathur, P.P.; et al. Signaling network map of endothelial Tek tyrosine kinase. J. Signal Transduct. 2014, 2014, 173026. [CrossRef] [PubMed]

131. Kontos, C.D.; Stauffer, T.P.; Yang, W.P.; York, J.D.; Huang, L.; Blanar, M.A.; Meyer, T.; Peters, K.G. Tyrosine 1101 of Tie2 is the major site of association of p85 and is required for activation of phosphatidylinositol 3-kinase and Akt. Mol. Cell Biol. 1998, 18, 4131-4140. [CrossRef] [PubMed]

132. Makinde, T.; Agrawal, D.K. Intra and extravascular transmembrane signalling of angiopoietin-1-Tie2 receptor in health and disease. J. Cell Mol. Med. 2008, 12, 810-828. [CrossRef] [PubMed]

133. Daly, C.; Wong, V.; Burova, E.; Wei, Y.; Zabski, S.; Griffiths, J.; Lai, K.M.; Lin, H.C.; Ioffe, E.; Yancopoulos, G.D.; et al. Angiopoietin-1 modulates endothelial cell function and gene expression via the transcription factor FKHR (FOXO1). Genes Dev. 2004, 18, 1060-1071. [CrossRef] [PubMed]

134. Jones, N.; Chen, S.H.; Sturk, C.; Master, Z.; Tran, J.; Kerbel, R.S.; Dumont, D.J. A unique autophosphorylation site on Tie2/Tek mediates Dok-R phosphotyrosine binding domain binding and function. Mol. Cell Biol. 2003, 23, 2658-2668. [CrossRef] [PubMed]

135. Hughes, D.P.; Marron, M.B.; Brindle, N.P. The antiinflammatory endothelial tyrosine kinase Tie2 interacts with a novel nuclear factor-kb inhibitor ABIN-2. Circ. Res. 2003, 92, 630-636. [CrossRef] [PubMed]

136. Tadros, A.; Hughes, D.P.; Dunmore, B.J.; Brindle, N.P. Abin-2 protects endothelial cells from death and has a role in the antiapoptotic effect of angiopoietin-1. Blood 2003, 102, 4407-4409. [CrossRef] [PubMed]

137. Ryu, J.K.; Kim, W.J.; Koh, Y.J.; Piao, S.; Jin, H.R.; Lee, S.W.; Choi, M.J.; Shin, H.Y.; Kwon, M.H.; Jung, K.; et al. Designed angiopoietin-1 variant, comp-angiopoietin-1, rescues erectile function through healthy cavernous angiogenesis in a hypercholesterolemic mouse. Sci. Rep. 2015, 5, 9222. [CrossRef] [PubMed]

138. Lekas, M.; Lekas, P.; Mei, S.H.; Deng, Y.; Dumont, D.J.; Stewart, D.J. Tie2-dependent neovascularization of the ischemic hindlimb is mediated by angiopoietin-2. PLOS ONE 2012, 7, e43568. [CrossRef] [PubMed]

139. Sun, X.D.; Liu, X.E.; Wu, J.M.; Cai, X.J.; Mou, Y.P.; Li, J.D. Expression and significance of angiopoietin-2 in gastric cancer. World J. Gastroenterol. 2004, 10, 1382-1385. [PubMed]

140. Mitsuhashi, N.; Shimizu, H.; Ohtsuka, M.; Wakabayashi, Y.; Ito, H.; Kimura, F.; Yoshidome, H.; Kato, A.; Nukui, Y.; Miyazaki, M. Angiopoietins and Tie-2 expression in angiogenesis and proliferation of human hepatocellular carcinoma. Hepatology 2003, 37, 1105-1113. [CrossRef] [PubMed]

141. Ahmad, S.A.; Liu, W.; Jung, Y.D.; Fan, F.; Wilson, M.; Reinmuth, N.; Shaheen, R.M.; Bucana, C.D.; Ellis, L.M. The effects of angiopoietin- 1 and -2 on tumor growth and angiogenesis in human colon cancer. Cancer Res. 2001, 61, 1255-1259. [PubMed]

142. Helfrich, I.; Edler, L.; Sucker, A.; Thomas, M.; Christian, S.; Schadendorf, D.; Augustin, H.G. Angiopoietin-2 levels are associated with disease progression in metastatic malignant melanoma. Clin. Cancer Res. 2009, 15, 1384-1392. [CrossRef] [PubMed]

143. Takanami, I. Overexpression of ang-2 mrna in non-small cell lung cancer: Association with angiogenesis and poor prognosis. Oncol. Rep. 2004, 12, 849-853. [CrossRef] [PubMed] 
144. Mazzieri, R.; Pucci, F.; Moi, D.; Zonari, E.; Ranghetti, A.; Berti, A.; Politi, L.S.; Gentner, B.; Brown, J.L.; Naldini, L.; et al. Targeting the Ang2/Tie2 axis inhibits tumor growth and metastasis by impairing angiogenesis and disabling rebounds of proangiogenic myeloid cells. Cancer Cell 2011, 19, 512-526. [CrossRef] [PubMed]

145. Holopainen, T.; Saharinen, P.; D'Amico, G.; Lampinen, A.; Eklund, L.; Sormunen, R.; Anisimov, A.; Zarkada, G.; Lohela, M.; Helotera, H.; et al. Effects of angiopoietin-2-blocking antibody on endothelial cell-cell junctions and lung metastasis. J. Natl. Cancer Inst. 2012, 104, 461-475. [CrossRef] [PubMed]

146. Nasarre, P.; Thomas, M.; Kruse, K.; Helfrich, I.; Wolter, V.; Deppermann, C.; Schadendorf, D.; Thurston, G.; Fiedler, U.; Augustin, H.G. Host-derived angiopoietin-2 affects early stages of tumor development and vessel maturation but is dispensable for later stages of tumor growth. Cancer Res. 2009, 69, 1324-1333. [CrossRef] [PubMed]

147. Machein, M.R.; Knedla, A.; Knoth, R.; Wagner, S.; Neuschl, E.; Plate, K.H. Angiopoietin-1 promotes tumor angiogenesis in a rat glioma model. Am. J. Pathol. 2004, 165, 1557-1570. [CrossRef]

148. Nakayama, T.; Yao, L.; Tosato, G. Mast cell-derived angiopoietin-1 plays a critical role in the growth of plasma cell tumors. J. Clin. Investig. 2004, 114, 1317-1325. [CrossRef] [PubMed]

149. Hawighorst, T.; Skobe, M.; Streit, M.; Hong, Y.K.; Velasco, P.; Brown, L.F.; Riccardi, L.; Lange-Asschenfeldt, B.; Detmar, M. Activation of the Tie2 receptor by angiopoietin-1 enhances tumor vessel maturation and impairs squamous cell carcinoma growth. Am. J. Pathol. 2002, 160, 1381-1392. [CrossRef]

150. Hayes, A.J.; Huang, W.Q.; Yu, J.; Maisonpierre, P.C.; Liu, A.; Kern, F.G.; Lippman, M.E.; McLeskey, S.W.; Li, L.Y. Expression and function of angiopoietin-1 in breast cancer. Br. J. Cancer 2000, 83, 1154-1160. [CrossRef] [PubMed]

151. Stoeltzing, O.; Ahmad, S.A.; Liu, W.; McCarty, M.F.; Wey, J.S.; Parikh, A.A.; Fan, F.; Reinmuth, N.; Kawaguchi, M.; Bucana, C.D.; et al. Angiopoietin-1 inhibits vascular permeability, angiogenesis, and growth of hepatic colon cancer tumors. Cancer Res. 2003, 63, 3370-3377. [PubMed]

152. Tait, C.R.; Jones, P.F. Angiopoietins in tumours: The angiogenic switch. J. Pathol. 2004, 204, 1-10. [CrossRef] [PubMed]

153. Papadopoulos, K.P.; Kelley, R.K.; Tolcher, A.W.; Razak, A.R.; Van Loon, K.; Patnaik, A.; Bedard, P.L.; Alfaro, A.A.; Beeram, M.; Adriaens, L.; et al. A phase I first-in-human study of nesvacumab (REGN910), a fully human Anti-Angiopoietin-2 (Ang2) monoclonal antibody, in patients with advanced solid tumors. Clin. Cancer Res. 2016, 22, 1348-1355. [CrossRef] [PubMed]

154. Daly, C.; Eichten, A.; Castanaro, C.; Pasnikowski, E.; Adler, A.; Lalani, A.S.; Papadopoulos, N.; Kyle, A.H.; Minchinton, A.I.; Yancopoulos, G.D.; et al. Angiopoietin-2 functions as a Tie2 agonist in tumor models, where it limits the effects of VEGF inhibition. Cancer Res. 2013, 73, 108-118. [CrossRef] [PubMed]

155. Bupathi, M.; Kaseb, A.; Janku, F. Angiopoietin 2 as a therapeutic target in hepatocellular carcinoma treatment: Current perspectives. Onco Targets Ther. 2014, 7, 1927-1932. [PubMed]

156. Dowlati, A.; Vlahovic, G.; Natale, R.B.; Rasmussen, E.; Singh, I.; Hwang, Y.C.; Rossi, J.; Bass, M.B.; Friberg, G.; Pickett, C.A. A phase I, first-in-human study of amg 780, an angiopoietin- 1 and -2 inhibitor, in patients with advanced solid tumors. Clin. Cancer Res. 2016, 22, 4574-4584. [CrossRef] [PubMed]

157. Kienast, Y.; Klein, C.; Scheuer, W.; Raemsch, R.; Lorenzon, E.; Bernicke, D.; Herting, F.; Yu, S.; The, H.H.; Martarello, L.; et al. Ang-2-VEGF-A CrossMab, a novel bispecific human IgG1 antibody blocking VEGF-A and Ang-2 functions simultaneously, mediates potent antitumor, antiangiogenic, and antimetastatic efficacy. Clin. Cancer Res. 2013, 19, 6730-6740. [CrossRef] [PubMed]

158. Baker, L.C.; Boult, J.K.; Thomas, M.; Koehler, A.; Nayak, T.; Tessier, J.; Ooi, C.H.; Birzele, F.; Belousov, A.; Zajac, M.; et al. Acute tumour response to a bispecific ang-2-VEGF-a antibody: Insights from multiparametric MRI and gene expression profiling. Br. J. Cancer 2016, 115, 691-702. [CrossRef] [PubMed]

159. Leow, C.C.; Coffman, K.; Inigo, I.; Breen, S.; Czapiga, M.; Soukharev, S.; Gingles, N.; Peterson, N.; Fazenbaker, C.; Woods, R.; et al. Medi3617, a human anti-angiopoietin 2 monoclonal antibody, inhibits angiogenesis and tumor growth in human tumor xenograft models. Int. J. Oncol. 2012, 40, 1321-1330. [CrossRef] [PubMed]

160. Nakamura, T.; Nawa, K.; Ichihara, A. Partial purification and characterization of hepatocyte growth factor from serum of hepatectomized rats. Biochem. Biophys. Res. Commun. 1984, 122, 1450-1459. [CrossRef]

161. Venepalli, N.K.; Goff, L. Targeting the HGF-cMET axis in hepatocellular carcinoma. Int. J. Hepatol. 2013, 2013, 341636. [CrossRef] [PubMed] 
162. Nakamura, T.; Mizuno, S. The discovery of hepatocyte growth factor (HGF) and its significance for cell biology, life sciences and clinical medicine. Proc. Jpn. Acad. Ser. B Phys. Biol. Sci. 2010, 86, 588-610. [CrossRef] [PubMed]

163. Organ, S.L.; Tsao, M.S. An overview of the c-Met signaling pathway. Ther. Adv. Med. Oncol. 2011, 3, S7-S19. [CrossRef] [PubMed]

164. Bottaro, D.P.; Rubin, J.S.; Faletto, D.L.; Chan, A.M.; Kmiecik, T.E.; Vande Woude, G.F.; Aaronson, S.A. Identification of the hepatocyte growth factor receptor as the c-Met proto-oncogene product. Science 1991, 251, 802-804. [CrossRef] [PubMed]

165. Comoglio, P.M.; Giordano, S.; Trusolino, L. Drug development of Met inhibitors: Targeting oncogene addiction and expedience. Nat. Rev. Drug Discov. 2008, 7, 504-516. [CrossRef] [PubMed]

166. Bardelli, A.; Ponzetto, C.; Comoglio, P.M. Identification of functional domains in the hepatocyte growth factor and its receptor by molecular engineering. J. Biotechnol. 1994, 37, 109-122. [CrossRef]

167. Cecchi, F.; Rabe, D.C.; Bottaro, D.P. The hepatocyte growth factor receptor: Structure, function and pharmacological targeting in cancer. Curr. Signal Transduct. Ther. 2011, 6, 146-151. [CrossRef] [PubMed]

168. Fixman, E.D.; Fournier, T.M.; Kamikura, D.M.; Naujokas, M.A.; Park, M. Pathways downstream of Shc and Grb2 are required for cell transformation by the tpr-Met oncoprotein. J. Biol. Chem. 1996, 271, 13116-13122. [CrossRef] [PubMed]

169. Pelicci, G.; Giordano, S.; Zhen, Z.; Salcini, A.E.; Lanfrancone, L.; Bardelli, A.; Panayotou, G.; Waterfield, M.D.; Ponzetto, C.; Pelicci, P.G.; et al. The motogenic and mitogenic responses to hgf are amplified by the shc adaptor protein. Oncogene 1995, 10, 1631-1638. [PubMed]

170. Ponzetto, C.; Bardelli, A.; Zhen, Z.; Maina, F.; Dalla Zonca, P.; Giordano, S.; Graziani, A.; Panayotou, G.; Comoglio, P.M. A multifunctional docking site mediates signaling and transformation by the hepatocyte growth factor/scatter factor receptor family. Cell 1994, 77, 261-271. [CrossRef]

171. Paumelle, R.; Tulasne, D.; Kherrouche, Z.; Plaza, S.; Leroy, C.; Reveneau, S.; Vandenbunder, B.; Fafeur, V. Hepatocyte growth factor/scatter factor activates the ETS1 transcription factor by a RAS-RAF-MEK-ERK signaling pathway. Oncogene 2002, 21, 2309-2319. [CrossRef] [PubMed]

172. Xiao, G.H.; Jeffers, M.; Bellacosa, A.; Mitsuuchi, Y.; Vande Woude, G.F.; Testa, J.R. Anti-apoptotic signaling by hepatocyte growth factor/Met via the phosphatidylinositol 3-kinase/Akt and mitogen-activated protein kinase pathways. Proc. Natl. Acad. Sci. USA 2001, 98, 247-252. [CrossRef] [PubMed]

173. Hui, A.Y.; Meens, J.A.; Schick, C.; Organ, S.L.; Qiao, H.; Tremblay, E.A.; Schaeffer, E.; Uniyal, S.; Chan, B.M.; Elliott, B.E. Src and fak mediate cell-matrix adhesion-dependent activation of met during transformation of breast epithelial cells. J. Cell Biochem. 2009, 107, 1168-1181. [CrossRef] [PubMed]

174. Rahimi, N.; Hung, W.; Tremblay, E.; Saulnier, R.; Elliott, B. C-src kinase activity is required for hepatocyte growth factor-induced motility and anchorage-independent growth of mammary carcinoma cells. J. Biol. Chem. 1998, 273, 33714-33721. [CrossRef] [PubMed]

175. Orian-Rousseau, V.; Chen, L.; Sleeman, J.P.; Herrlich, P.; Ponta, H. CD44 is required for two consecutive steps in HGF/c-Met signaling. Genes Dev. 2002, 16, 3074-3086. [CrossRef] [PubMed]

176. Trusolino, L.; Bertotti, A.; Comoglio, P.M. A signaling adapter function for $\alpha 6 \beta 4$ integrin in the control of HGF-dependent invasive growth. Cell 2001, 107, 643-654. [CrossRef]

177. Fischer, O.M.; Giordano, S.; Comoglio, P.M.; Ullrich, A. Reactive oxygen species mediate met receptor transactivation by $\mathrm{G}$ protein-coupled receptors and the epidermal growth factor receptor in human carcinoma cells. J. Biol. Chem. 2004, 279, 28970-28978. [CrossRef] [PubMed]

178. Lee, D.; Sung, E.S.; Ahn, J.H.; An, S.; Huh, J.; You, W.K. Development of antibody-based c-Met inhibitors for targeted cancer therapy. ImmunoTargets Ther. 2015, 4, 35-44. [PubMed]

179. Zhu, H.; Naujokas, M.A.; Park, M. Receptor chimeras indicate that the met tyrosine kinase mediates the motility and morphogenic responses of hepatocyte growth/scatter factor. Cell Growth Differ. 1994, 5, 359-366. [PubMed]

180. Bladt, F.; Riethmacher, D.; Isenmann, S.; Aguzzi, A.; Birchmeier, C. Essential role for the c-met receptor in the migration of myogenic precursor cells into the limb bud. Nature 1995, 376, 768-771. [CrossRef] [PubMed]

181. Schmidt, C.; Bladt, F.; Goedecke, S.; Brinkmann, V.; Zschiesche, W.; Sharpe, M.; Gherardi, E.; Birchmeier, C. Scatter factor/hepatocyte growth factor is essential for liver development. Nature 1995, 373, 699-702. [CrossRef] [PubMed] 
182. Cooper, C.S.; Park, M.; Blair, D.G.; Tainsky, M.A.; Huebner, K.; Croce, C.M.; Vande Woude, G.F. Molecular cloning of a new transforming gene from a chemically transformed human cell line. Nature 1984, 311, $29-33$. [CrossRef]

183. Liang, T.J.; Reid, A.E.; Xavier, R.; Cardiff, R.D.; Wang, T.C. Transgenic expression of TPR-MET oncogene leads to development of mammary hyperplasia and tumors. J. Clin. Investig. 1996, 97, 2872-2877. [CrossRef] [PubMed]

184. Soman, N.R.; Correa, P.; Ruiz, B.A.; Wogan, G.N. The TPR-MET oncogenic rearrangement is present and expressed in human gastric carcinoma and precursor lesions. Proc. Natl. Acad. Sci. USA 1991, 88, 4892-4896. [CrossRef] [PubMed]

185. Corso, S.; Comoglio, P.M.; Giordano, S. Cancer therapy: Can the challenge be met? Trends Mol. Med. 2005, 11, 284-292. [CrossRef] [PubMed]

186. Wang, R.; Ferrell, L.D.; Faouzi, S.; Maher, J.J.; Bishop, J.M. Activation of the met receptor by cell attachment induces and sustains hepatocellular carcinomas in transgenic mice. J. Cell Biol. 2001, 153, 1023-1034. [CrossRef] [PubMed]

187. Takayama, H.; LaRochelle, W.J.; Sharp, R.; Otsuka, T.; Kriebel, P.; Anver, M.; Aaronson, S.A.; Merlino, G. Diverse tumorigenesis associated with aberrant development in mice overexpressing hepatocyte growth factor/scatter factor. Proc. Natl. Acad. Sci. USA 1997, 94, 701-706. [CrossRef] [PubMed]

188. Gordon, M.S.; Sweeney, C.S.; Mendelson, D.S.; Eckhardt, S.G.; Anderson, A.; Beaupre, D.M.; Branstetter, D.; Burgess, T.L.; Coxon, A.; Deng, H.; et al. Safety, pharmacokinetics, and pharmacodynamics of AMG 102, a fully human hepatocyte growth factor-neutralizing monoclonal antibody, in a first-in-human study of patients with advanced solid tumors. Clin. Cancer Res. 2010, 16, 699-710. [CrossRef] [PubMed]

189. Kakkar, T.; Ma, M.; Zhuang, Y.; Patton, A.; Hu, Z.; Mounho, B. Pharmacokinetics and safety of a fully human hepatocyte growth factor antibody, AMG 102, in cynomolgus monkeys. Pharm. Res. 2007, 24, 1910-1918. [CrossRef] [PubMed]

190. Burgess, T.; Coxon, A.; Meyer, S.; Sun, J.; Rex, K.; Tsuruda, T.; Chen, Q.; Ho, S.Y.; Li, L.; Kaufman, S.; et al. Fully human monoclonal antibodies to hepatocyte growth factor with therapeutic potential against hepatocyte growth factor/c-Met-dependent human tumors. Cancer Res. 2006, 66, 1721-1729. [CrossRef] [PubMed]

191. Iveson, T.; Donehower, R.C.; Davidenko, I.; Tjulandin, S.; Deptala, A.; Harrison, M.; Nirni, S.; Lakshmaiah, K.; Thomas, A.; Jiang, Y.; et al. Rilotumumab in combination with epirubicin, cisplatin, and capecitabine as first-line treatment for gastric or oesophagogastric junction adenocarcinoma: An open-label, dose de-escalation phase $1 \mathrm{~b}$ study and a double-blind, randomised phase 2 study. Lancet Oncol. 2014, 15, 1007-1018. [CrossRef]

192. D'Arcangelo, M.; Cappuzzo, F. Focus on the potential role of ficlatuzumab in the treatment of non-small cell lung cancer. Biologics 2013, 7, 61-68. [CrossRef] [PubMed]

193. Patnaik, A.; Weiss, G.J.; Papadopoulos, K.P.; Hofmeister, C.C.; Tibes, R.; Tolcher, A.; Isaacs, R.; Jac, J.; Han, M.; Payumo, F.C.; et al. Phase I ficlatuzumab monotherapy or with erlotinib for refractory advanced solid tumours and multiple myeloma. Br. J. Cancer 2014, 111, 272-280. [CrossRef] [PubMed]

194. Bann, D.V.; Deschler, D.G.; Goyal, N. Novel immunotherapeutic approaches for head and neck squamous cell carcinoma. Cancers 2016, 8, 87. [CrossRef] [PubMed]

195. Okamoto, W.; Okamoto, I.; Tanaka, K.; Hatashita, E.; Yamada, Y.; Kuwata, K.; Yamaguchi, H.; Arao, T.; Nishio, K.; Fukuoka, M.; et al. Tak-701, a humanized monoclonal antibody to hepatocyte growth factor, reverses gefitinib resistance induced by tumor-derived HGF in non-small cell lung cancer with an EGFR mutation. Mol. Cancer Ther. 2010, 9, 2785-2792. [CrossRef] [PubMed]

196. Parikh, R.A.; Wang, P.; Beumer, J.H.; Chu, E.; Appleman, L.J. The potential roles of hepatocyte growth factor (HGF)-met pathway inhibitors in cancer treatment. OncoTargets Ther. 2014, 7, 969-983.

197. Merchant, M.; Ma, X.; Maun, H.R.; Zheng, Z.; Peng, J.; Romero, M.; Huang, A.; Yang, N.Y.; Nishimura, M.; Greve, J.; et al. Monovalent antibody design and mechanism of action of onartuzumab, a MET antagonist with anti-tumor activity as a therapeutic agent. Proc. Natl. Acad. Sci. USA 2013, 110, E2987-E2996. [CrossRef] [PubMed] 
198. Spigel, D.R.; Edelman, M.J.; O’Byrne, K.; Paz-Ares, L.; Mocci, S.; Phan, S.; Shames, D.S.; Smith, D.; Yu, W.; Paton, V.E.; et al. Results from the phase III randomized trial of onartuzumab plus erlotinib versus erlotinib in previously treated stage IIIb or IV non-small-cell lung cancer: Metlung. J. Clin. Oncol. 2017, 35, 412-420. [CrossRef] [PubMed]

199. Spigel, D.R.; Ervin, T.J.; Ramlau, R.A.; Daniel, D.B.; Goldschmidt, J.H., Jr.; Blumenschein, G.R., Jr.; Krzakowski, M.J.; Robinet, G.; Godbert, B.; Barlesi, F.; et al. Randomized phase II trial of onartuzumab in combination with erlotinib in patients with advanced non-small-cell lung cancer. J. Clin. Oncol. 2013, 31, 4105-4114. [CrossRef] [PubMed]

200. Rosen, L.S.; Goldman, J.W.; Algazi, A.P.; Turner, P.K.; Moser, B.; Hu, T.; Wang, X.A.; Tuttle, J.; Wacheck, V.; Wooldridge, J.E.; et al. A first-in-human phase I study of a bivalent MET antibody, emibetuzumab (ly2875358), as monotherapy and in combination with erlotinib in advanced cancer. Clin. Cancer Res. 2017, 23, 1910-1919. [CrossRef] [PubMed]

201. Liu, L.; Zeng, W.; Wortinger, M.A.; Yan, S.B.; Cornwell, P.; Peek, V.L.; Stephens, J.R.; Tetreault, J.W.; Xia, J.; Manro, J.R.; et al. Ly2875358, a neutralizing and internalizing anti-met bivalent antibody, inhibits HGF-dependent and HGF-independent MET activation and tumor growth. Clin. Cancer Res. 2014, 20, 6059-6070. [CrossRef] [PubMed]

202. Zelensky, A.N.; Gready, J.E. The C-type lectin-like domain superfamily. FEBS J. 2005, 272, $6179-6217$. [CrossRef] [PubMed]

203. Mura, M.; Swain, R.K.; Zhuang, X.; Vorschmitt, H.; Reynolds, G.; Durant, S.; Beesley, J.F.; Herbert, J.M.; Sheldon, H.; Andre, M.; et al. Identification and angiogenic role of the novel tumor endothelial marker CLEC14A. Oncogene 2012, 31, 293-305. [CrossRef] [PubMed]

204. Rho, S.S.; Choi, H.J.; Min, J.K.; Lee, H.W.; Park, H.; Kim, Y.M.; Kwon, Y.G. Clec14a is specifically expressed in endothelial cells and mediates cell to cell adhesion. Biochem. Biophys. Res. Commun. 2011, 404, 103-108. [CrossRef] [PubMed]

205. Ki, M.K.; Jeoung, M.H.; Choi, J.R.; Rho, S.S.; Kwon, Y.G.; Shim, H.; Chung, J.; Hong, H.J.; Song, B.D.; Lee, S. Human antibodies targeting the C-type lectin-like domain of the tumor endothelial cell marker CLEC14A regulate angiogenic properties in vitro. Oncogene 2013, 32, 5449-5457. [CrossRef] [PubMed]

206. Khan, K.A.; Naylor, A.J.; Khan, A.; Noy, P.J.; Mambretti, M.; Lodhia, P.; Athwal, J.; Korzystka, A.; Buckley, C.D.; Willcox, B.E.; et al. Multimerin-2 is a ligand for group 14 family C-type lectins CLEC14A, CD93 and CD248 spanning the endothelial pericyte interface. Oncogene 2017. [CrossRef] [PubMed]

207. Noy, P.J.; Lodhia, P.; Khan, K.; Zhuang, X.; Ward, D.G.; Verissimo, A.R.; Bacon, A.; Bicknell, R. Blocking CLEC14A-MMRN2 binding inhibits sprouting angiogenesis and tumour growth. Oncogene 2015, 34, 5821-5831. [CrossRef] [PubMed]

208. Jang, J.H.; Kim, M.R.; Lee, W.R.; Kim, J.H.; Heo, K.; Lee, S. CLEC14A-hsp70-1a interaction regulates hsp70-1a-induced angiogenesis. Sci. Rep. 2017, under revision.

209. Zanivan, S.; Maione, F.; Hein, M.Y.; Hernandez-Fernaud, J.R.; Ostasiewicz, P.; Giraudo, E.; Mann, M. Silac-based proteomics of human primary endothelial cell morphogenesis unveils tumor angiogenic markers. Mol. Cell Proteom. 2013, 12, 3599-3611. [CrossRef] [PubMed]

210. Mancuso, P.; Calleri, A.; Gregato, G.; Labanca, V.; Quarna, J.; Antoniotti, P.; Cuppini, L.; Finocchiaro, G.; Eoli, M.; Rosti, V.; et al. A subpopulation of circulating endothelial cells express CD109 and is enriched in the blood of cancer patients. PLoS ONE 2014, 9, e114713. [CrossRef] [PubMed]

211. Krishna Priya, S.; Kumar, K.; Hiran, K.R.; Bindhu, M.R.; Nagare, R.P.; Vijaykumar, D.K.; Ganesan, T.S. Expression of a novel endothelial marker, C-type lectin 14a, in epithelial ovarian cancer and its prognostic significance. Int. J. Clin. Oncol. 2017, 22, 107-117. [CrossRef] [PubMed]

212. Kim, T.; Park, C.S.; Jang, J.H.; Kim, M.R.; Na, H.; Lee, K.; Yoo, B.C.; Kim, Y.; Lee, J.; Kim, S.J.; et al. Inhibition of VEGF-dependent angiogenesis and tumor angiogenesis by an optimized antibody targeting CLEC14A. Mol. Oncol. 2017, under revision.

(c) 2017 by the authors. Licensee MDPI, Basel, Switzerland. This article is an open access article distributed under the terms and conditions of the Creative Commons Attribution (CC BY) license (http:// creativecommons.org/licenses/by/4.0/). 